\title{
Article \\ Nutrition as a Key Modifiable Factor for Periodontitis and Main Chronic Diseases
}

\author{
Prescilla Martinon ${ }^{1}$, Laurie Fraticelli ${ }^{1} @$, Agnes Giboreau ${ }^{2}$, Claude Dussart ${ }^{1} @$, Denis Bourgeois ${ }^{1} \mathbb{C}$ \\ and Florence Carrouel $1, * \mathbb{B}$
}

1 Laboratory "Systemic Health Care", University of Lyon, University Claude Bernard Lyon 1, EA4129, 69008 Lyon, France; prescilla.martinon@univ-lyon1.fr (P.M.); laurie.fraticelli@univ-lyon1.fr (L.F.); claude.dussart@univ-lyon1.fr (C.D.); denis.bourgeois@univ-lyon1.fr (D.B.)

2 Institute Paul Bocuse Research Center, 69130 Ecully, France; agnes.giboreau@institutpaulbocuse.com

* Correspondence: florence.carrouel@univ-lyon1.fr; Tel.: +33-4-78-78-57-44

Citation: Martinon, P.; Fraticelli, L.; Giboreau, A.; Dussart, C.; Bourgeois, D.; Carrouel, F. Nutrition as a Key Modifiable Factor for Periodontitis and Main Chronic Diseases. J. Clin. Med. 2021, 10, 197. https://doi.org/ 10.3390/jcm10020197

Received: 1 December 2020

Accepted: 4 January 2021

Published: 7 January 2021

Publisher's Note: MDPI stays neutral with regard to jurisdictional clai$\mathrm{ms}$ in published maps and institutional affiliations.

Copyright: (C) 2021 by the authors. Licensee MDPI, Basel, Switzerland. This article is an open access article distributed under the terms and conditions of the Creative Commons Attribution (CC BY) license (https:// creativecommons.org/licenses/by/ $4.0 /)$.

\begin{abstract}
Nutrition is recognized as an essential component in the prevention of a number of chronic diseases, including periodontal disease. Based on these considerations, a better understanding is required regarding how the diet, and more particularly the intake of macronutrients and micronutrients, could impact the potential relationship between nutrition and periodontal diseases, periodontal diseases and chronic diseases, nutrition and chronic diseases. To overcome this complexity, an up-todate literature review on the nutriments related to periodontal and chronic diseases was performed. High-sugar, high-saturated fat, low-polyols, low-fiber and low-polyunsaturated-fat intake causes an increased risk of periodontal diseases. This pattern of nutrients is classically found in the Western diet, which is considered as an 'unhealthy' diet that causes cardiovascular diseases, diabetes and cancers. Conversely, low-sugar, high-fiber and high-omega-6-to-omega-3 fatty acid ratio intake reduces the risk of periodontal diseases. The Mediterranean, DASH, vegetarian and Okinawa diets that correspond to these nutritional intakes are considered as 'healthy' diets, reducing this risk of cardiovascular diseases, diabetes and cancers. The role of micronutrients, such as vitamin $\mathrm{D}, \mathrm{E}, \mathrm{K}$ and magnesium, remains unclear, while others, such as vitamin A, B, C, calcium, zinc and polyphenols have been shown to prevent PDs. Some evidence suggests that probiotics and prebiotics could promote periodontal health. Periodontal and chronic diseases share, with a time delay, nutrition as a risk factor. Thus, any change in periodontal health should be considered as a warning signal to control the dietary quality of patients and thus reduce the risk of developing chronic diseases later on.
\end{abstract}

Keywords: chronic diseases; periodontal diseases; prevention; nutrition; diet; nutriment; risk factor

\section{Introduction}

Nutrition is a critical component of lifelong health and development [1]. Better nutrition improves the health of infants, children and adults, reinforces the immune system, promotes safer pregnancy and childbirth, contributes to longevity and reduces the risk of non-communicable diseases [2]. Thus, nutrition and health are strongly connected. Today, the world is facing a double burden of malnutrition, including both undernutrition and overnutrition. Both forms of malnutrition are a major challenge to human health [3]. Increasing rates of overweight and obesity around the world are accompanied by soaring rates of chronic diseases (CDs) such as cardiovascular diseases (CVDs), diabetes and cancer [4,5]. It is, however, important not to link malnutrition only with obesity and major CDs. Periodontal disease (PD) is a noncommunicable disease with a $45-50 \%$ global prevalence, with $11 \%$ of the global population suffering from a severe form, which makes it the sixth most common disease [6]. The high prevalence of PDs among teenagers, adults and seniors is a public health problem [7]. PDs are oral multifactorial immunological, inflammatory diseases induced by oral microorganisms. 
Nutrient diversity has a significant impact on periodontal conditions for all ages [8]. Balanced nutrition plays a major role in maintaining the symbiosis between oral microbiota and periodontal health [9]. Although many macro- and micronutrients enter the gastrointestinal tract through saliva, the chewing process is an essential element of the nutrient acquisition process. It involves the integrity of the periodontal tissue, influenced by several factors, such as tobacco, oral hygiene, epigenetic and genetic factors, nutrition and systemic health.

Moreover, an association exists between PDs and major CDs, such as CVD, diabetes, and stroke, as well as lung disease and rheumatoid arthritis $[10,11]$. Individuals with PD have a $19 \%$ greater risk of suffering from CVDs than healthy individuals and this risk reaches $44 \%$ in individuals 65 years of age and older [7]. It is also suggested that there is a bidirectional long-term impact of periodontitis and the main non communicable diseases $[12,13]$.

Nutrition, PDs and the major CDs thus form an interdependent relationship throughout life. The so-called 'common risk factors approach', which is well accepted in public health, combines the prevention of CDs with the control of PDs, primarily by addressing a diversity of modifiable factors such as dietary risk factors e.g., micro- and macronutrients, sugar consumption, and alcohol abuse [14]. This approach suggests that a combination of interventions on the lowest common denominator, i.e., nutrition, could improve health outcomes. To the best of our knowledge, the potential three-directional interactions between nutrition, PDs and CDs have never been analyzed.

The aim of this review was to collect available scientific data on the potential relationship between nutrition/PD, nutrition/CDs, and PDs/CDs. The objective is to assess if a combined nutrition strategy could contribute to reducing $C D$ risk through a reduction in the severity and incidence of PDs.

\section{Materials and Methods}

A review based on the principles of a scoping review was conducted to provide an overview of the available research evidence $[15,16]$. Unlike systematic reviews that involve a comprehensive search for studies with specific designs, the scoping review is particularly useful when the information on a topic is complex and diverse [17]. This method allows the inclusion of all study designs using the following steps: (1) identification of a clear research objective and search strategies, (2) selection of relevant publications, (3) categorization of the publications, (4) extraction of data, and (5) summarizing, analyzing and reporting the results.

\subsection{Selection Process of Publications}

The general characteristics of scoping reviews included in this study are reported in Figure 1.

\subsubsection{Identification Strategy}

Publications in English from September 2010 to September 2020 were identified in PubMed using the following search terms:

- $\quad$ Nutrition-PDs associations: "nutrition" (All Fields) OR "diet" (All fields) AND "periodontal disease" (All Fields) AND “humans" (MeSH Terms);

- Nutrition-CDs associations: "nutrition" (All Fields) OR "diet" (All fields) AND "chronic disease" (MeSH Terms) AND "humans" (MeSH Terms) AND ("cardiovascular disease" (All fields) OR "diabetes" (All fields) OR "cancer" (All fields);

- $\quad$ PDs-other CDs: "periodontal disease" (All Fields) AND "humans" (MeSH Terms) AND "chronic disease".

Congress abstracts or commentaries were excluded. A total of 1451 publications were identified, with 303 studies for nutrition-PDs, 968 studies for nutrition-CDs and 180 for PDs-other CDs (Figure 1). 


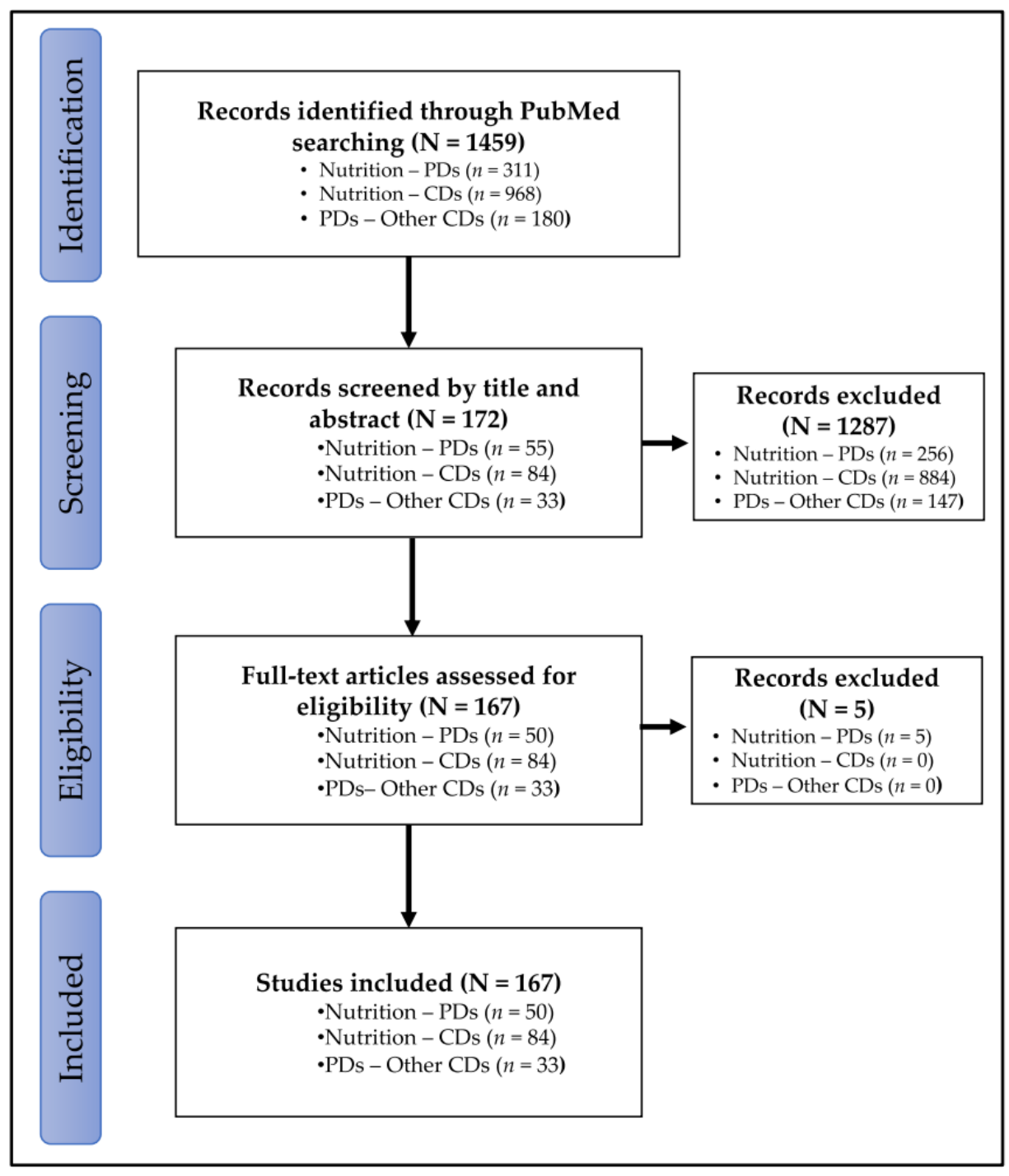

Figure 1. Flowchart of study selection process. CDs: chronic diseases; PD: periodontal diseases.

\subsubsection{Screening and Eligibility of Publications}

Selection was refined by reading the titles and abstracts of the 1459 studies. Thus, 1287 publications were excluded because they concerned specific populations (pregnant women, elderly), behavioral aspects (mastication, hygiene) or beverages (alcohol, coffee, tea or, sodas). The full texts of the remaining 172 publications were then screened. Five publications out the scope were excluded, whereas the 167 remaining publications were included (Figure 1).

\subsection{Determination of the Link between Nutrition, Periodontal Diseases and Other} Chronic Diseases

2.2.1. Classification of Publications According to the Level of Evidence

From the 167 publications, the studies were classified by level of evidence [18]: nonexperimental studies (i.e., observational studies: case reports, case control studies and cohort studies), experimental studies (i.e., randomized controlled trials) and reviews (i.e., systemic reviews and meta-analyzes) (Figure 2). 


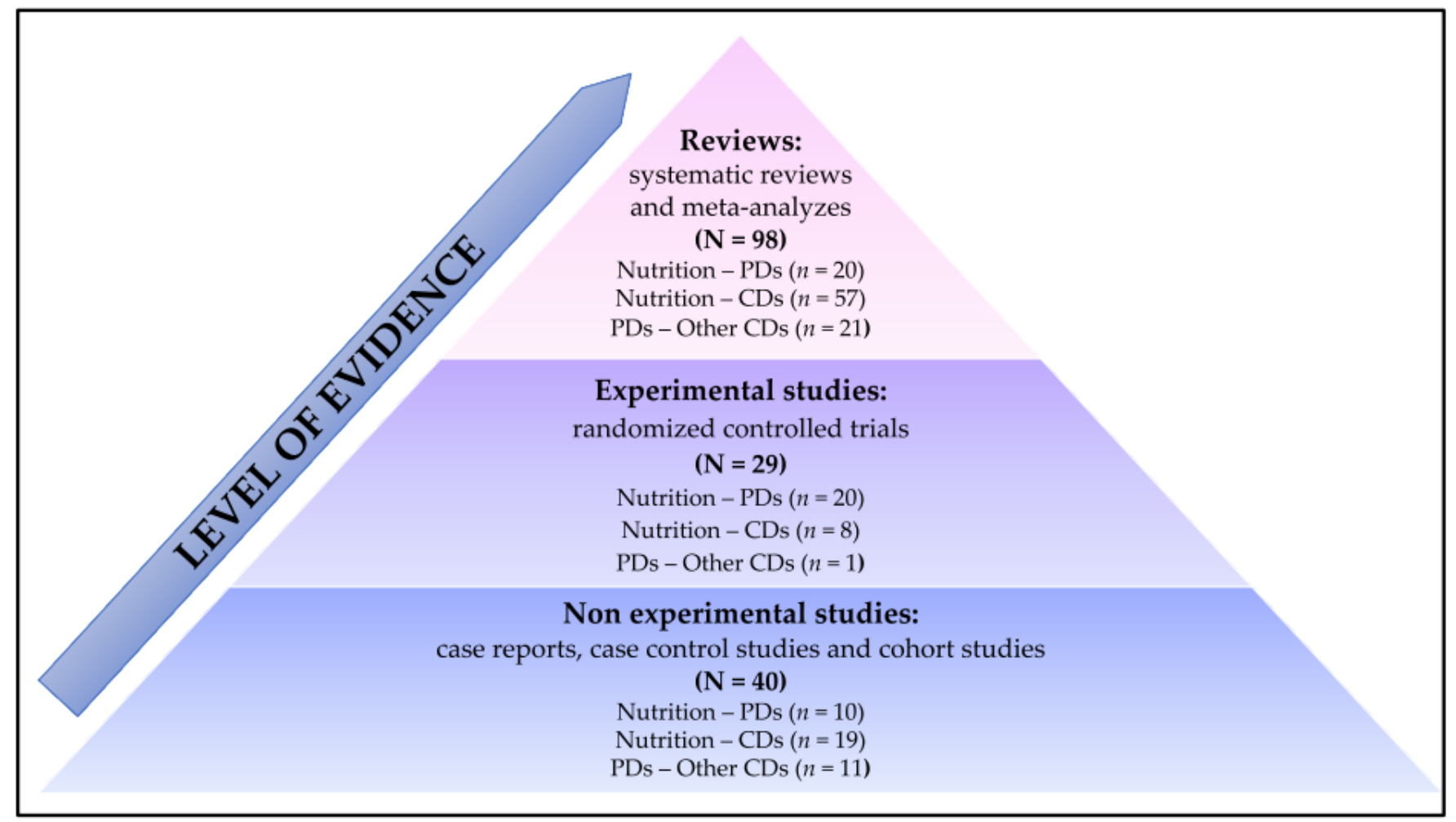

Figure 2. Classification of publications according to the level of evidence. CDs: chronic diseases; PD: periodontal diseases.

2.2.2. Data Extraction from the Included Relevant Studies and Classification of Publications According to the GRADE Process and Summarizing of the Results

For each publication in each level of evidence and category (nutrition-PDs, nutritionCDs or PDs-other CDs), the size of the study population, the study design, objectives, results and conclusions obtained were analyzed and coded using the GRADE process. The GRADE process was used to assess the quality of the studies $[19,20]$. The publications were graded independently by two assessors using the following levels:

- High: The true effect lies close to that of the estimate of the effect;

- $\quad$ Moderate: The true effect is likely to be close to the estimate of the effect, but there is a possibility that it is substantially different;

- Low: The true effect may be substantially different from the estimate of the effect;

- Very low: The true effect is likely to be substantially different from the estimate of effect.

Any discordant grading was discussed by the assessors until a consensus was reached.

\subsubsection{Summarizing of the Results}

The assessors then determined the resulting grade for nutrition-PDs, nutrition-CDs and PDs-other CDs by combining the results obtained from the level of evidence and from the GRADE process. The following codifications were used: high $(\bullet \bullet \bullet \bullet)$, moderate $(\bullet \bullet \bullet \bigcirc)$, low $(\bullet \bullet \bigcirc)$ and very low $(\bullet \bigcirc \bigcirc \bigcirc)$. Any discordant grading was discussed by the assessors until a consensus was reached. The results are summarized in Figure 3. 


\section{Modifiable risk factors}

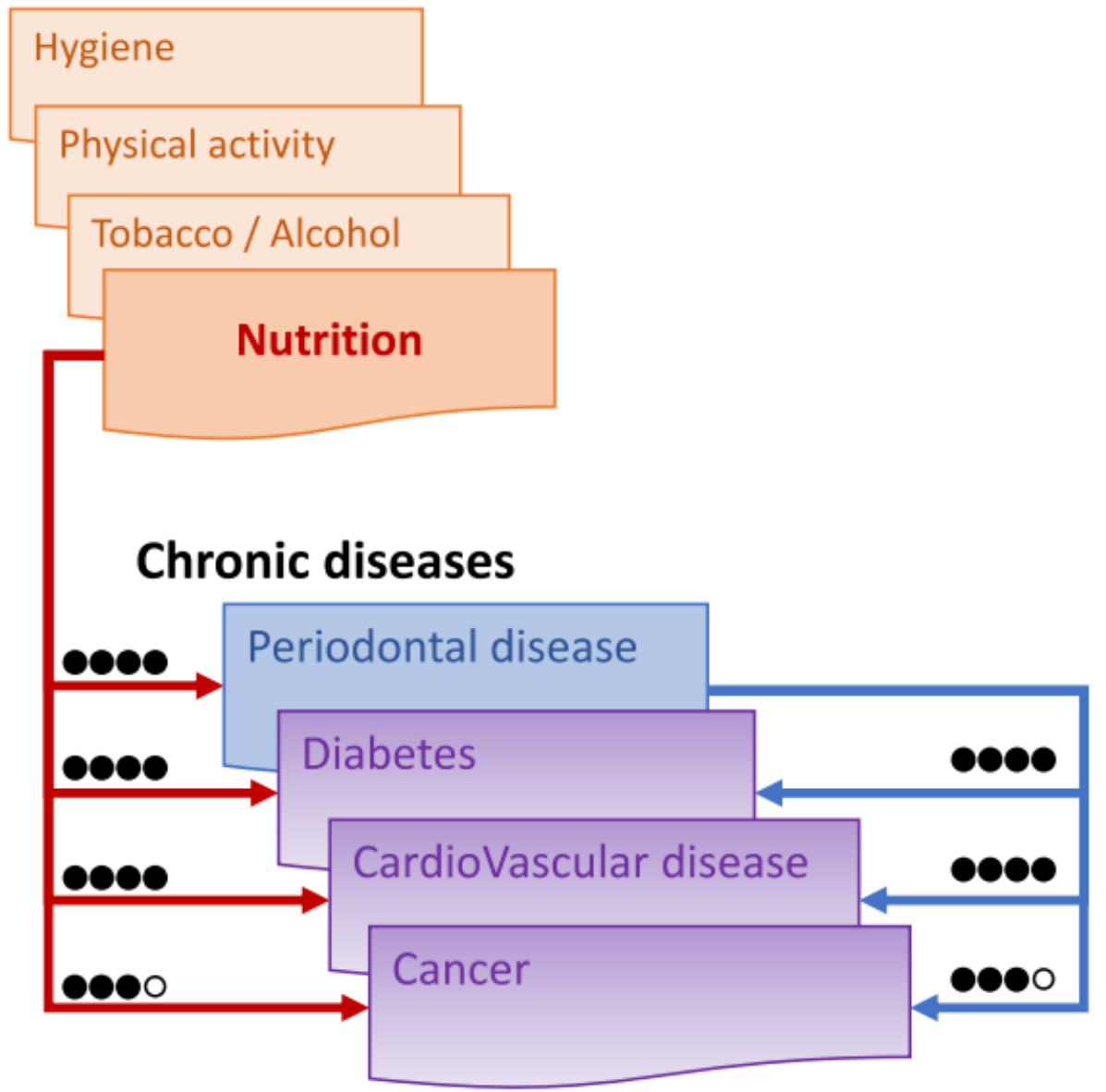

Figure 3. Assessment of the links between nutrition, periodontitis and other main chronic diseases

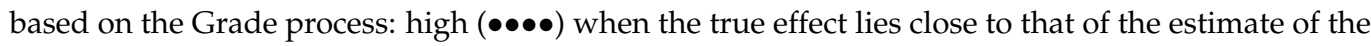
effect, moderate $(\bullet \bullet \bullet)$ when likely to be close to the estimate of the effect, but there is a possibility that it is substantially different, low $(\bullet \bullet \bigcirc \bigcirc)$ when may be substantially different from the estimate of the effect, and very low $(\bullet \bigcirc \bigcirc)$ ) when likely to be substantially different from the estimate of effect.

\section{Link between Nutrition, Periodontitis and Other Main Chronic Diseases: Research} Outcomes

3.1. Nutrition as Risk Factor of Periodontal Diseases

3.1.1. Impact of Macronutriments on Periodontal Diseases

Macronutrients consist of carbohydrates, proteins and fats. These are the nutrients from the food supply that provide energy to the body and ensure the proper functioning of its vital functions.

Carbohydrates are composed of sugars, starches and fibers that have different effects on PDs. While sugar and starches are sources of glucose, fibers are a nondigestible form of carbohydrates [21]. The main sources of carbohydrates are fruits, vegetables, whole grains, milk, and milk products. While grains and certain vegetables (potatoes and corn) are rich in starch, sweet potatoes are rich in sucrose. Dark-green vegetables and fruits are sources of sugars and dietary fiber [21]. Based on the American Dental Association guideline goal, the 2010 dietary guidelines for Americans, and carbohydrate consumption, Feinman et al. (2015) have defined a high-carbohydrate diet as a diet in which carbohydrates make up more than $45 \%$ of total energy intake and a low-carbohydrate diet as a diet in which carbohydrates make up less than $26 \%$ of total energy intake [22]. In the cohort of the National Health And Nutrition Examination Survey (NHANES) data, a high consumption of added sugar was associated with a higher PD prevalence ratio of 1.42 (95\% CI, 1.08-1.85) [23]. 
The risk of gingival infection decreased to approximately half when the consumption of carbohydrates was restricted in a four-week diet [24]. Depending on the nature of the carbohydrates consumed, the effect on PD will be different. An excessive consumption of sugar or refined carbohydrates promoted microbiota dysbiosis that induced an inflammatory reaction and caused the apparition of PDs [25,26] (Table 1). Moreover, glucose acts on periodontal ligament cells by promoting their apoptosis and inhibiting their proliferation [27]. Conversely, polyols and fibers demonstrated a protective effect on the prevention of PDs (Table 1). Xylitol produced by the hydrogenation of xylose sugar had an antibacterial effect against Porphyromonas gingivalis (P. gingivalis) and Aggregatibacter actinomycetemcomitans (A. actinomycetemcomitans), two periodontal bacteria [28-30]. The results from a double-blind, randomized controlled trial comparing the effect of sugar-free chewing gum sweetened with xylitol or maltitol with a chewing gum base or no gum on gingivitis and plaque scores coupled with brushing or not showed that a reduction in sugar consumption, associated with scaling and root planing, and the use of gums containing xylitol or maltitol, can improve periodontal health [29]. The difference observed could be due to the fact that contrary to glucose, polyols are not metabolized by most oral bacteria [31]. Dietary fiber intake is inversely correlated to PD, as demonstrated in the analysis of the results of the cohort NHANES (2009-2012) [22] (Table 1). Salazar et al. (2018) also concluded that there was an inverse association between PD and higher consumption of whole-grains and fruits [32]. The protective effect of fibers against PDs could be explained because they improve glycemic control [33], which is an established risk factor for periodontitis.

Table 1. Nutrients and their rule in the risk of periodontal disease.

\begin{tabular}{|c|c|c|}
\hline \multicolumn{2}{|c|}{ Nutrients } & Risk of Periodontal Disease ${ }^{1}$ \\
\hline \multicolumn{3}{|c|}{ Macronutrients } \\
\hline \multirow{5}{*}{ Carbohydrates } & Sugars & $\uparrow(\bullet \bullet \bullet \bullet)$ \\
\hline & Polyols & $\downarrow(\bullet \bullet \bullet \bullet)$ \\
\hline & Fibers & $\downarrow(\bullet \bullet \bullet \bullet)$ \\
\hline & Saturated fatty acids & $\uparrow(\bullet \bullet \bullet \bullet)$ \\
\hline & Polyunsaturated fatty acids & $\downarrow(\bullet \bullet \bullet \bullet)$ \\
\hline \multicolumn{3}{|c|}{ Micronutrients } \\
\hline \multirow{6}{*}{ Vitamins } & Vitamin A & $\downarrow(\bullet \bullet \bullet \bullet)$ \\
\hline & Vitamin B & $\downarrow(\bullet \bullet \bullet \bigcirc)$ \\
\hline & Vitamin C & $\downarrow(\bullet \bullet \bullet \bullet)$ \\
\hline & Vitamin D & $\downarrow(\bullet \bigcirc \bigcirc \bigcirc)$ \\
\hline & Vitamin E & $\downarrow(\bullet \bigcirc \circ 0)$ \\
\hline & Vitamin K & Not determined \\
\hline \multicolumn{2}{|c|}{ Calcium } & $\downarrow(\bullet \bullet \bullet \bigcirc)$ \\
\hline \multicolumn{2}{|c|}{ Magnesium } & $\downarrow(\bullet \bigcirc \bigcirc \bigcirc)$ \\
\hline \multicolumn{2}{|c|}{ Iron } & $\downarrow(\bullet \bigcirc \bigcirc \bigcirc)$ \\
\hline \multicolumn{2}{|c|}{ Zinc } & $\downarrow(\bullet \bullet \bigcirc \bigcirc)$ \\
\hline \multicolumn{2}{|c|}{ Polyphenols } & $\downarrow(\bullet \bullet \bullet \bullet)$ \\
\hline \multicolumn{2}{|c|}{ Prebiotics and probiotics } & $\downarrow(\bullet \bigcirc \bigcirc \bigcirc)$ \\
\hline
\end{tabular}

${ }^{1}$ Increased risk of periodontal disease is indicated by the symbol $\uparrow$ and decreased risk of periodontal disease is indicated by the symbol $\downarrow$. The level of evidence was codified: high $(\bullet \bullet \bullet \bullet)$, moderate $(\bullet \bullet \bullet)$, low $(\bullet \bullet \bigcirc \bigcirc)$ and very low $(\bullet \bigcirc \bigcirc)$.

Fatty acids consist of a straight alkyl chain, terminating with a carboxyl group. The number of carbons in the chain varies, and the compound may be saturated (containing no double bonds) or unsaturated (containing at least one double bond). Milk fat, coconut oil and palm oil are sources of short- and medium-chain saturated fatty acids (SFA) (4-12 carbons). Long-chain SFAs (>14 carbons) are found in other vegetable and animal fats. Many food sources are composed of different fatty acids. Olive oil contains monounsaturated fatty acids, saturated and polyunsaturated fatty acids [34]. We identified only one study evaluating the impact of total fat intake on PDs [35]. In this study, Hamasaki et al. (2017) 
analyzed the results of the 2005 National Health and Nutrition Survey and demonstrated a positive association between low fat intake (23.2\% of the total energy) and PDs [35]. More than the total fat intake, it is the nature of the fat that must be considered [34]. The SFA intake could enhance oxidative stress, which has been shown to be associated with PDs, exerting its effects by damaging cells [36]. One other study demonstrated that omega-3 fatty acid (polyunsaturated fatty acids) has a positive impact on PDs whereas SFAs have a negative impact [37] (Table 1). Other authors focused on the omega-6 (polyunsaturated fatty acids) to omega-3 fatty acid ratio [24]. In a review, Bosma-den Boer et al. concluded that a modern, Western lifestyle, composed of refined carbohydrates and a high Omega- 6 to Omega-3 fatty acid ratio promotes inflammatory processes [25]. In a randomized controlled pilot study, Woelber et al. (2017) obtained similar results concerning the correlation between a high Omega-6 to Omega-3 fatty acid ratio and PD [24]. The positive effect observed of a decrease in the Omega-6 to Omega-3 fatty acid ratio on PD [24] supports the theory of resoleomics described by Serhan et al. [38] and the related periodontal studies [39-41].

\subsubsection{Impact of Micronutrients on Periodontal Disease}

Micronutrients consist of vitamins, minerals and trace elements. These are nutrients without energy value, but which are essential for chemical reactions and therefore vital to the body.

The presence of vitamins in the diet is important for maintaining periodontal health and preventing PDs [8,42] (Table 1). In a minireview, Gondivkar et al. (2018) described the association of PDs with deficiencies of vitamins A, C, E, folic acid and calcium [43]. Moreover, the antioxidant effects of vitamins can have a positive impact on the prevention and treatment of PDs [8].

Vitamin A is a group of fat-soluble compounds that are metabolically linked to all-trans retinol [44]. Animal-derived food such as milk, cheese, liver and eggs are sources of preformed vitamin A, whereas carrots, green leaves, broccoli, ripe mangos, sweet potato, orange-yellow vegetables, fruits and red palm oil are sources of provitamin A carotenoids [8,44]. According to the UK National Health Service, men aged from 19-64 years need $0.7 \mathrm{mg} /$ day of vitamin A compared with $0.6 \mathrm{mg} /$ day for women of the same age [44]. Several studies have concluded that vitamin A deficiency was linked to the PDs [44]. Conversely, the increase in the amount of beta-carotene ( $\geq 7.07 \mathrm{mg} /$ day) consumed is linked to a decrease in the number of sites with a probing depth $>3 \mathrm{~mm}$ after scaling and root planing [45]. Vitamin A is thought to have a role in the maintenance of the integrity of epithelial cells [43].

The vitamin B complex family consists of thiamine (B1), riboflavin (B2), niacin (B3), pantothenic acid (B5), pyridoxine, pyridoxal, pyridoxamine (B6), biotin (B7), folic acid (B9), and cobalamin (B12). For adults $200 \mu \mathrm{g} /$ day of vitamin B9, present in leafy greens and fortified cereals, and $1.5 \mu \mathrm{g} /$ day of vitamin B12, present in fortified cereals, meat and fish, are recommended according to the UK National Health [44]. Few studies have analyzed the association between vitamin B and PDs. However, deficiency in vitamin B complex results in lower resistance to bacterial infections, which could explain the role of vitamin $B$, particularly vitamin B9, in PDs [43]. In a prospective cohort, Zong et al. analyzed the potential association between serum vitamin B12 with changes in periodontitis [46]. They demonstrated that an increase in serum vitamin B12 was associated with a decrease in the clinical parameters of PD (probing pocket depth, clinical attachment loss and, the tooth loss) [46].

Vitamin C (ascorbic acid) can be found in many fruits and vegetables. According to the UK National Health, a dose of $40 \mathrm{mg}$ /day is recommended for adults [44]. Several studies have demonstrated that a low level of vitamin $C$ was associated with PD [8,44]. In a multicenter, randomized, parallel-group, controlled clinical trial comprising 300 individuals with gingivitis, Shimabukuro et al. concluded that toothpaste with vitamin $C$ and magnesium salt can reduce gingival inflammation [47]. Compared with conventional toothpaste, this toothpaste exhibited a significantly higher activity against reactive oxygen species, which might be associated with the onset and progression of gingival inflammation [47]. 
Vitamin D, which comes mainly from fortified cereals, mushrooms and fish, enhances the absorption of minerals such as calcium, iron, magnesium, phosphate and zinc [48]. It is composed of two groups, vitamin D2 (cholecalciferol) and vitamin D3 (ergocalciferol). The UK National Health recommends intake of $10 \mu \mathrm{g} /$ day for adults [44]. Several clinical studies have demonstrated an association between a dietary vitamin $\mathrm{D}$ deficiency and PDs [49-51]. However, other studies have concluded that there is no link between the levels of serum vitamin $\mathrm{D}$ and periodontal health $[49,52]$. The link between vitamin $\mathrm{D}$ and PDs remains unclear and needs further investigation.

The vitamin E complex family consists of eight naturally occurring, lipid-soluble antioxidant micronutrients, four of which are tocopherols and four are tocotrienols. They are the most important lipid-soluble antioxidant and they prevent lipid peroxidation [44]. The major food sources are vegetable oils, fortified cereals, nuts, seeds, meats, fruits and vegetables [53]. The UK National Health Service recommends $4 \mathrm{mg} /$ day for men and $3 \mathrm{mg} /$ day for women, but in the USA the recommended daily intake is $15 \mathrm{mg}$ [44,53]. Pfeiffer et al. concluded that there was no significant association between serum vitamin E levels and PDs [54]. However, in a more recent cross-sectional study including 4708 participants, an inverse association between serum alpha-tocopherols and PD severity was reported [55]. This difference could be attributed to fact that Zong et al. (2015) considered confounding factors such as blood lipids [55].

Vitamin $\mathrm{K}$ is a group of vitamins that plays a role in the synthesis of proteins that are precursors for blood coagulation factors, such as prothrombin and factors VII, IX, and $X$ [56]. It also plays a role in the synthesis of proteins required for bone metabolism, such as periostin and osteocalcin. Kale, collards, spinach, and mustard are a source of vitamin K [8]. Vitamin K deficiency is thought to be associated with gingival bleeding; it was reported that vitamin K supplement failed to reduce pro-inflammatory factors in the periodontum in a rat model [57]. However, to our knowledge, no articles have studied the link between vitamin $\mathrm{K}$ and PD in humans.

Calcium is essential for the maintenance and formation of calcified tissues such as bone or teeth. The recommended daily intake for adults 19-64 years of age is $700 \mathrm{mg}$ according to the UK National Health Service [44]. It is present in milk products, eggs, fish, leafy vegetables, seeds and nuts [8]. Several reviews conclude that a calcium-deficient diet was associated with PDs $[8,44]$ (Table 1). In a recent cross-sectional study, Adegboye et al. demonstrated that the calcium intake was inversely correlated with PDs in Danish adults [58]. Tanaka et al., in a cross-sectional study including 1162 Japanese women with a mean age of 31.5 years, reported, after adjustment for age, smoking status, region of residence, education, household income, toothbrushing frequency and use of an interdental brush, an association between a calcium intake of $>585 \mathrm{mg} /$ day and a lower prevalence of PDs [59].

Magnesium, found mainly in cereals, nuts, seeds cocoa, soybeans, spinach, marine vegetables and tomatoes, is also essential for the maintenance and formation of calcified tissues such as bone or teeth, but its association with periodontal health is unclear $[8,44]$ (Table 1). The UK National Health Service recommends daily dose for men is $300 \mathrm{mg} /$ day and $270 \mathrm{mg} /$ day for women [44]. In the only study identified assessing the association between magnesium and PDs, Staudte et al. recorded the 7-day food intake in 42 patients with chronic periodontitis and 38 healthy subjects and reported a negative effect of magnesium-poor diets on periodontal health [60]. However, more studies are necessary before we can conclude on the effect of magnesium intake on periodontal health.

Iron plays a crucial role in oxygen transport by hemoglobin [44]. It is also an essential cofactor for many enzymes, whose function is reduced if there is an inadequate supply of iron. The recommended daily dose of iron for men aged from 19-64 years old and for women aged from 50-64 years old $8.7 \mathrm{mg}$, and for women aged from 19 to 50 years, it is $14.8 \mathrm{mg}$ according to the UK National Health Service [44]. Rich food sources of iron are fish (salmon and tuna), red meat, spinach, and dry beans [8]. In a recent study, Chakraborty et al. indicated that iron-deficiency anemia was associated with a reduction in antioxidant enzymes, and so to an increase in oxidative stress and a worsening of 
PDs [61]. However, no studies have studied the correlation between iron supplements and PDs (Table 1).

After iron, zinc is the most abundant trace mineral necessary for the body. The primary source of dietary zinc is protein-rich foods, spinach, nuts, fortified cereals $[8,44,62]$. Zinc is a cofactor in enzyme-controlled processes and it also has antioxidative properties [8,44]. Zinc starves reactive oxygen species and neutralizes bacterial toxins [63]. The UK National Health Service recommends that the daily dose for men is $9.5 \mathrm{mg}$, and $7.0 \mathrm{mg}$ for women [44]. Adverse effects such as suppression of immune responses, decrease in high-density-lipoprotein cholesterol, reduction in copper absorption, and impairment of copper status have been described in case of excess intake of zinc supplements [44]. Two studies demonstrated that low serum zinc levels were associated with PDs [64,65].

Polyphenols are physiological compounds present in plants. Wine, red fruits, vegetables, grapes, green tea and coffee are food sources of polyphenols [66]. Most polyphenols have antioxidative and anti-inflammatory properties [66]. Several studies concluded on the positive effect of polyphenol in the prevention and treatment of PD. In a clinical study, it was observed in healthy patients that the use of pomegranate juice mouthwash (rich in polyphenols, tannins, ellagic acid and anthocyanins) significantly reduced the growth of Lactobacillus and Streptococcus species [67]. In PD patients, the application of a gel containing $1 \%$ curcumin (a bioactive substance of turmeric) to the affected areas in the periodontal pockets had significant bactericidal effects on Capnocytophaga, F. nucleatum, P. intermedia and $P$. gingivalis [68]. The effect of polyphenols has also been demonstrated on the clinical signs of PD. In a randomized clinical trial, the daily oral intake of fruit/vegetable-containing capsules reduced the pocket depth in patients with chronic PD [69]. Grover et al. (2016) demonstrated that the subgingival application of a gel containing 10\% of Emblica officinalis or gooseberry extract reduced inflammation, pocket depth and the sulcus bleeding index [70]. In patients with PD, the use of green tea extract gel (1\%) containing epigallocatechin gallate or green tea extract toothpaste with $60-90 \%$ epigallocatechin gallate decreased the clinical signs of PD [71,72].

\subsubsection{Impact of Probiotics and Prebiotics on Periodontal Disease}

Probiotics are defined as "living microorganisms, mostly bacteria, non-pathogenic, used as nutritional supplements, which after being ingested in the right amount, improve the intestinal microbial balance and cause beneficial effects on the health of those who ingest them" [73]. Some probiotics are thought to have a function in the maintenance of periodontal health and the treatment of PD. In a review, Matsubara et al. analyzed 12 RCTs and concluded that oral administration of Lactobacillus reuteri (DSM17938, ATCC $55,730+$ ATCC PTA5289, $1 \times 10^{8} \mathrm{CFU}$ ), Lactobacillus salivarius (WB21, $6.7 \times 10^{8} \mathrm{CFU}$ ) and Lactobacillus brevis (CD2, $\left.0.2 \times 10^{8} \mathrm{CFU}\right)$ had a positive impact on the clinical signs of $\mathrm{PD}$ and reduced the levels of major periodontal pathogens; however, the benefits were maintained only with continuous probiotic administration [74]. Morales et al. raised the same conclusions for the same strains and also concluded on the Lactobacillus plantarum (L137) in supportive periodontal therapy [75]. Several mechanism could explain the action of probiotics: (i) production of lactic acid that inhibits the proliferation of periodontal bacteria by penetrating the membrane of bacteria and acidifying the cytoplasm, (ii) production of hydrogen peroxide that inhibits the growth of pathogenic bacteria, (iii) modification of proteins at the level of the site of attachment, (iv) production of inhibitory substances such as bacteriocins, (v) production of vitamins or other substances [75].

Prebiotics are "non-digestible food ingredients that beneficially affect the host by selectively stimulating the growth and/or activity of one or a limited number of bacteria in the colon, and thus improves host health" [76]. In the only study selected for this review, Chandra et al. (2016), reported the efficacy of a probiotic, Saccharomyces boulardii $\left(1.6 \times 10^{9} \mathrm{CFU}\right)$, mixed in a ratio $4: 1$ with a prebiotic, fructooligosaccharide, in the treatment of PD when used as an adjunct to non-surgical periodontal therapy [77]. 
Thus, our review of the literature demonstrated that nutrition has an essential role in the development of PD (Figure 3). Particularly, the composition of the diet in terms of the main macronutrients and micronutrients was responsible for the onset of PDs. There is insufficient evidence of an association between prebiotics and probiotics and PDs.

\subsection{Nutrition as a Risk Factor for Chronic Diseases}

Human nutrition varies according to cultural, religious, and ideological practices, and it also can be modified by health concerns. Among the many diets around the world, some have been reported to have an impact on CDs. The Mediterranean diet, the Okinawa diet, the Dietary Approaches to Stop Hypertension (DASH) and the Vegetarian diet are reported to have a positive impact on CDs such as CVDs, diabetes and cancers, whereas the Western diet is reported to be an unhealthy diet [78].

\subsubsection{Unhealthy Diets: Western Diets}

Western diets have high calorie count and are high in proteins, fatty acids and sugar [79]. They consist mainly of meat, industrialized food, sugar, refined grains, alcohol, salt and fructose, with an associated reduced consumption of fruits and vegetables [79]. Many people in the United States and many other Western countries have adopted this diet. The evidence shows that a diet high in saturated fat and sucrose increases the risk of several chronic conditions including CVD, diabetes and cancers, compared with a diet of low-energy foods, such as fruits and vegetables [80].

In a meta-analysis of 22 cohort studies Rodríguez-Monforte et al., (2015) reported in a comparison of the highest and the lowest category of Western diets, the pooled relative risk for CVD, stroke and coronary heart disease was 1.14 (95\% CI, 0.92-1.42), 1.05 (95\% CI 0.91-1.22), and 1.03 (95\% CI 0.90-1.17), respectively [81]. However, other observational studies and reviews concluded to a significant increased risk in case of PD [82,83]. In a cohort study, Oikonomou et al. (2018), observed that the Western dietary pattern was predictive of severe coronary artery disease (AUC: 0.73, 95\% CI, 0.64-0.83, $p<0.001)$. The high consumption of ultra-processed foods-commonly high in one or more of the following element: calories, saturated fat, sugar or sodium-seems to be one key element of the association between the Western diet and the higher risk of cardiovascular, cerebrovascular, and coronary heart diseases [84]. The salt content in these diets could be another key element because WHO estimated that a decrease in salt intake from the current global levels (9-12 gm/day) to the recommended level (5 gm/day) would have a major impact on reducing blood pressure and the incidence of CVDs [85]. In a study including 31,672 subjects, He et al. (2014) observed that a decrease of $1.9 \mathrm{~g}$ of $24 \mathrm{~h}$ urinary sodium was associated with a reduction in $42 \%$ of stroke deaths and $40 \%$ of coronary heart disease deaths [86]. Additionally, the Western diet contains additives, such as sweeteners, emulsifiers, thickeners, preservatives and food colorings, some of which have already been associated with $\mathrm{CD}$, such as coronary diseases [79].

In a matched case-control study, Beigrezaei et al., (2019) observed that Western diet significantly increased the risk of type-2 diabetes (OR: 9.25, 95\% CI, 4.95-17.4) [87]. Nagao et al. observed the same correlation [88]. Meat in the Western diets could be responsible due to their composition in high saturated fatty acid content that are responsible for obesity, hyperinsulinemia and hyperglycemia. The higher sugar intake observed in Western diets is also associated with the increasing risk of type 2 diabetes [89].

Western diets were reported to have a negative impact on the risk of colorectal, stomach and prostate cancers but not on the risk of breast, esophagus and rectal cancers [80,90-98]. The consumption of high quantities of meat in the Western diet could be one of the key elements of its impact on cancer. The International Agency for Research on Cancer has classified red meat and processed meat as "probably carcinogenic to humans' and 'carcinogenic to humans", respectively [99]. In an observational study including 104,980 participants, Fiolet et al. (2018) demonstrated that the overall risk of cancer was increased by $10 \%$ if the proportion of ultraprocessed foods was increased by $10 \%$ [100]. However, results from a meta-analysis failed 
to show a positive correlation between red and processed meat, cooking methods, and the concentration of heterocyclic amines with the risk of prostate cancer [101]. Thus, Western diets may have a more complex impact on cancer risk than the impact from processed and red meat as individual aliments.

\subsubsection{Healthy Diets: Mediterranean Diet, Okinawa Diet, Dietary Approaches to Stop} Hypertension and Vegetarian Diet

- Impact of the Mediterranean diet on CDs

The Mediterranean diet is associated with a high intake of extra-virgin olive oil, fruits, vegetables, nuts, cereals and legumes, moderate intakes of fish, and low intakes of red meat, sweets and eggs [102]. This diet is rich in polyphenols, lycopene, trace elements, minerals, vitamins and omega-3 fatty acids [103]. Studies conclude that the Mediterranean diet, known as a "long life" diet, even when it is adapted to other countries' eating habits, has a key role in health promotion and CD prevention [104,105]. In an umbrella review of meta-analyses of cohort studies, Galbete et al. reported a 19-27\% lower risk of developing CVDs (e.g., coronary heart disease, stroke), a 13-23\% lower risk of developing type-2 diabetes and a $14 \%$ lower risk of cancer mortality in subjects adhering to the Mediterranean diet compared with those with the lowest adherence levels to the diet [106].

In an observational prospective population-based cohort study including 23,232 men and women, Paterson et al. (2018) reported that subjects adhering to a Mediterranean diet had a lower risk of stroke [107]. In an observational study including 1284 patients hospitalized for an acute or chronic ischemic heart disease Siki et al. (2017) reported similar reductions in risk [108]. Based on the analysis of data from the National Nutrition and Physical Activity Survey, including 9435 subjects, Aridi et al. reported that higher adherence to a Mediterranean diet decreased the incidence of CDs, with lower concentrations of total cholesterol, low-density lipoprotein, diastolic blood pressure and dyslipidemia [109]. One key component of this diet is the olive oil that acts on the risk of CVDs by (i) reducing the concentrations of low-density lipoproteins, (ii) increasing the concentration of highdensity lipoproteins [110] and, (ii) downregulating pro-inflammatory cytokines such as interleukin-6 and tumor necrosis factor [111].

The positive impact of the Mediterranean diet on type-2 diabetes was also observed in several studies [112-114]. The results from the PREDIMED (PREvención con DIeta MEDiterránea) randomized trial, showed a reduction of $40 \%$ in the incidence of type-2 diabetes in subjects adopting the Mediterranean diet with extra-virgin olive oil but without energy restriction compared with subjects adopting a low-fat control diet [115]. In a recent review Martín-Peláez et al. analyzed clinical trials and prospective cohort studies including more than 100,000 participants [116]. They reported similar results and underlined that the positive impact is due to olive oil, which helps glycemic control by lowering fasting plasma glucose and HbA1c. The preventive action of the diet is probably due to the anti-inflammatory and antioxidative properties of its components. The diet is thought to act by improving autophagy, Th cells imbalance, cell adhesion, complement activity and oxidative stress [103].

The Mediterranean diet also was reported to have a positive impact on the risk of cancer [117-120]. For example, in a European cohort, with 5,296,617 person-years of followup, Bamia et al. observed an 8-11\% decreased risk of colorectal cancer in subjects adhering to the diet [121]. In a multicenter case-control study, high adherence to a Mediterranean diet was associated with an almost 35\% reduction in risk of bladder cancer compared with low adherence [122]. It is thought that the components of the diet reduce the cancer risk by reducing tumor cell growth through anti-oxidative and anti-inflammatory effects (vegetables, fruit, and olive oil), increasing chemoprotective effects (olive oil), and inhibiting tumor development (dairy products) [123-126];

- Impact of other Mediterranean-type diets on chronic diseases

The Okinawa and Dietary Approaches to Stop Hypertension (DASH) diets have a similar composition to that of Mediterranean diets [127]. 
The DASH diet is rich in vegetables and fruits, whole grains, low-fat dairy products, poultry, fish, nuts, beans and seeds. Compared with a Western diet it, contains less sugar, sodium, fats and red meat. This diet is rich in nutrients (protein, magnesium, calcium, potassium and fiber) and poor in trans-fatty acids, saturated acids and cholesterol. In a literature review of prospective cohort studies, Chiavaroli et al. (2019) reported that the DASH diet was associated with a decrease in the incidence of CVD $(\mathrm{RR}=0.80 ; 95 \% \mathrm{CI}$, $0.76-0.85)$, coronary heart disease ( $R R=0.79 ; 95 \% \mathrm{CI}, 0.71-0.88)$, stroke $(\mathrm{RR}=0.81 ; 95 \% \mathrm{CI}$, 0.72-0.92), and diabetes ( $R R=0.82 ; 95 \%$ CI, 0.74-0.92) [128]. Mohsenpour et al. (2019) reported that high adherence to a DASH diet plan was associated with a decrease in any cancer mortality ( $R R=0.84 ; 95 \% C I, 0.81-0.86$ ) [129]. Several systematic reviews, including randomized controlled trials and observational prospective studies, reported the association of the DASH diet plan with lower risks for CVDs, coronary heart disease, stroke, heart failure, diabetes, and several types of cancer [130-136].

The Okinawa diet is rich in vegetables (green, yellow and roots) and fibers, has a moderate fish intake and low calorie, meat, dairy product, fat, and carbohydrate intake. In contrast with the traditional Japanese diet, the traditional Okinawa diet consists of smaller quantities of rice, replaced by sweet potato $[78,137]$. The Okinawan diet has only $30 \%$ of the average Japanese sugar intake, and this is mainly from fruit [78]. However, the Okinawa diet has disadvantages, including high sodium intake (soy sauce, miso soup), and unnecessary restrictions of specific food groups (e.g., meat, eggs) $[78,137]$. Although the Okinawa diet has been reported to have a positive impacts on the prevention of CDs, not many studies have been published in the last 10 years $[78,137,138]$.

- Impact of vegetarian diet on chronic diseases

The vegetarian diet is a mode of nutrition based on the exclusion of all meat poultry and fish. Vegetarian diets are classified in different subgroup: vegetarian diet (no animal meat, but consumes eggs and milk), semi-vegetarian (occasional meat consumption), lactoovo-pesco-vegetarian (consumes fish) and vegan (no animal-derived products) [139]. In general, vegetarian diets are associated with health benefits and the results from some studies show that vegetarians tended to have a better quality diet than meat-eaters and a higher intake of important nutrients like fiber, vitamin C, vitamin E and magnesium [140].

The adherence to a vegetarian diet was shown to be associated with a reduction in CVD mortality [141]. In a meta-analysis including seven studies and 12,4706 subjects, Huang et al. (2012) reported a significant lower mortality due to coronary disease in vegetarians $(\mathrm{RR}=0.71 ; 95 \% \mathrm{CI}, 0.56-0.87)$ compared with non-vegetarians [142]. Similar results were reported by Kwok et al., (2014) and Dinu et al., (2017) [143,144]. The vegetarian diet has a positive impact on CVD risk factors, such as blood pressure, blood lipids, platelet aggregation, obesity, and metabolic syndrome $[141,145,146]$. The vegetarian diet has a role in the prevention of CVDs as well as in its treatment [141].

An important impact of the vegetarian diet was demonstrated in the prevention and treatment of diabetes $[147,148]$. In an observational study including 2918 subjects, Chiu et al., (2018) found that the adherence to a vegetarian diet for 5 years reduced the incidence of diabetes by $35 \%$. A decrease of $53 \%$ was observed for subjects adhering to a vegetarian diet after having been non-vegetarian [149]. In a randomized controlled trial including 74 subjects, Kahleova et al. (2011) concluded that $43 \%$ of subjects adhering to a vegetarian diet were able to reduce the use of diabetes medication to treat compared with non-vegetarians [150]. A systematic review that included six studies reported an association of vegetarian diet and improved blood sugar control in people with type 2 diabetes [145].

The vegetarian diet seems to decrease the overall cancer risk [151]. In a case-control study including 469 subjects, Chang et al. (2017) observed a lower risk of breast cancer in vegetarians [152]. Similar results were obtained by Tantamango-Bartley et al. (2013) [153]. A vegetarian diet decreased the risk of cancers of the gastrointestinal tract $(\mathrm{HR}=0.76$; 95\% CI, 0.63-0.90) [153]. A vegan diet reduced the overall incidence of cancer ( $\mathrm{HR}=0.84$; $95 \% \mathrm{CI}, 0.72-0.99)$ and the risk of prostate cancer (HR $=0.65 ; 95 \% \mathrm{CI}: 0.49-0.85)[153,154]$. A lacto-ovo-vegetarian diet had a positive impact on the risk of gastrointestinal cancers 
$(\mathrm{HR}=0.75 ; 95 \% \mathrm{CI}, 0.60-0.92)$ [153]. A pesco-vegetarian diet reduced the risk of colorectal cancer [155]. In contrast to these results, a review by Molina-Montes et al. (2020) explained that due to the low number of studies available (five studies included), it was not possible to conclude that a vegetarian diet had a preventive role on the overall incidence of cancer [151].

Although there is evidence that vegetarian diets can prevent CDs, it is important to acknowledge that vegetarian diets have some risks. This diet is rich in linoleic acid (LA) and poor in alpha-linolenic acid (ALA), with a higher LA to ALA ratio than the recommended 4:1 ratio [156]. In 2020, Fallon et al. highlighted that vegetarian and vegan diets could be associated with a lower intake of vitamins (B12 and D), calcium, iodine and selenium in UK adult women [157]. These micronutrients play a key role in fetal development, and low intake results in a negative impact on CDs. In the long-term, vegetarian diets low in legumes, nuts and/or dairy and eggs could have a negative impact on health due to severe protein deficiencies which could increase risk muscle wasting or atrophy [158], or Kwashiorkor disease in cases of extreme severe deficiency, although there are not many publications about this [159].

The results from our review demonstrated that the diet could have an adverse or positive impact on CDs. It confirmed a strong association between nutrition and CVDs and nutrition and diabetes but only a more moderate association between nutrition and cancer, which was dependent on the type of cancer (Figure 3). The diet pattern and the nutrients have an impact on CD risk. The Nutrition and CDs Expert group reported that fruit, vegetables, beans/legumes, seafood, fish, nuts/seeds, yogurt, fiber, whole grains, omega-3, polyunsaturated fats and potassium all had protective cardiometabolic effects, and processed and unprocessed red meats, beverages, trans-fats, glycemic load and sodium all had negative cardiometabolic effects [160].

\subsection{Periodontal Diseases as Risk Factors of Other Main Chronic Diseases}

\subsubsection{Association between Periodontitis and the Main Chronic Diseases}

PDs have been reported to be associated with CDs such as CVD, diabetes, respiratory diseases, rheumatoid arthritis, cancers, Alzheimer disease [10,161,162]. In our review, we focused on the main CDs (cardiovascular diseases, diabetes and cancers).

PDs have been reported to be associated with several CVDs, such as peripheral arterial disease, stroke, and ischemic heart disease $[10,163,164]$. Statistically significant associations were found between CVD and gingivitis (OR $=4.30 ; 95 \% \mathrm{CI}, 1.85-10.00)$, and CVD and periodontitis (OR = 2.87; 95\% CI, 1.04-7.93) [165]. In a literature review of 22 observational studies, $\mathrm{Xu}$ et al. (2017) observed an increased risk of myocardial infarction associated with PDs (OR = 2.02; 95\% CI, 1.59-2.57) [166]. These data were confirmed by several other articles [167-169]. The link between PD and stroke was reported in several reviews [170,171]. Leira et al. (2017) reported a relative risk of 2.52 (95\% CI, 1.77-3.58) for pooled cohort studies and 3.04 (95\% CI, 1.10-8.43) for pooled case-control studies [170]. PDs were also reported to be associated with coronary heart disease [172]. Although the association between PD and CVDs has been reported, the causal association is not clear as PDs and CVDs exhibit multifactorial etiologies and share a common risk. However, periodontal bacteria seem to have a key role since biopsies of 17 coronary arteries in patients with atherosclerosis revealed that periodontal pathogens was present in approximately $60 \%$ of samples: P. gingivalis was present in 52.9\%, A. actinomycetemcomitans, in 35.5\%, Prevotella intermedia, in 23.5\%, and Tannerella forsythia, in $11.7 \%$ [173].

Analyses of the National Health and Nutrition Examination Survey (2009-2010, 1165 diabetes-free adults) showed that the PD was positively associated with prevalent impaired glucose tolerance, a sign of prediabetes [174]. This association could be explained by the fact that PDs could alter glycemic control by increasing the resistance of tissues to insulin [175]. The treatment of PDs can improve glycemic control supporting this explanation [176-180]. The dysbiosis of oral microbiota could explain the association between PDs and diabetes because the subgingival microbial profile, particularly for three bacteria (Tannerella forthysia, P. gingivalis and $A$. actinomycetemcomitans), are different in patients with and without diabetes [181]. The 
concentrations of $P$. gingivalis were significantly higher in patients with uncontrolled diabetes compared with those with controlled diabetes [182].

A positive correlation between PDs and pancreas, head, neck and lung cancers has been reported [162]. Corbella et al. (2018) reported a trend of increased cancer risk in patients with PDs but could not conclude because of the small number of studies [183]. Güven et al. (2019) reported a negative association between PDs and cancers in an observational study, including 5199 patients [184]. With a follow-up of 7.2 years, patients with PDs had a $17 \%$ higher risk of cancer compared with those without PDs, for the same age groups and gender. PDs increased the risk of pancreas cancer ( $R R=1.74 ; 95 \% C I, 1.41-2.15)$ [185]. Similar results were obtained for lung cancer $(\mathrm{HR}=1.24 ; 95 \% \mathrm{CI}, 1.13-1.36)$ [186], breast cancer $(\mathrm{RR}=1.22 ; 95 \% \mathrm{CI}, 1.06-1.40)$ [187], oral cancers (OR $=3.21 ; 95 \% \mathrm{CI}, 2.25-4.16)$ [188], head and neck cancer $(\mathrm{OR}=2.63 ; 95 \% \mathrm{CI}, 1.1 .68-4.14)$ [189]. Periodontal pathogens could be responsible for the association between PDs and cancer. Some periodontal bacteria have been observed in the organs affected by cancer. For example, P. gingivalis was found at significantly elevated levels in patients with oral squamous cell carcinoma [190] and squamous cell carcinoma of the esophagus [191]. The presence of Fusobacterium nucleatum was higher in human colon adenomas, compared with the surrounding tissues, and in stool samples from patients with colorectal cancer, compared with those without colorectal cancer [192].

The evidence from this review supports PDs as risk factors for CVDs, type-2 diabetes and cancers. The presence of oral bacteria, particularly periodontal bacteria, could be responsible for this association [10,193,194].

\subsubsection{Periodontal Bacteria as the Link between Periodontal Diseases and Chronic Diseases}

The main factors responsible for PDs are the presence of periodontal pathogens, such as P. gingivalis, Treponema denticola and Tannerella forsythia in the subgingival microbiota [195]. These periodontal bacteria induce a dysbiosis of the microbiota, and the resulting inflammatory process leads to $\mathrm{PD}$. These bacteria, their bacterial products and the inflammatory molecules produced in response to the presence of these bacteria can circulate, via the blood and the digestive pathways, to attain different organs $[10,196,197]$. The presence of oral bacteria in various organs involved in systemic pathologies has been reported in patients suffering from PD [196,197]:

- Diffusion of bacteria via blood

Bacterial penetration from the oral cavity into the underlying tissues and the blood system is only possible if one of the protective systems is defective. This failure can take place at the level of (i) the physical protection provided by oral epithelium which contains antimicrobial peptides, (ii) the electrical protection, due to the difference between the host cell and the bacterial layer, (iii) immunological protection by antibody-producing cells, (iv) phagocytic protection by the reticulo-endothelial system [196]. Patients with PDs have a high risk of bacteremia due to the increasing number of periodontal bacteria [196]. Generally, the microorganisms, which are mainly anaerobic bacteria, will be eliminated by the reticuloendothelial system within a few minutes and do not cause other clinical symptoms except for a possible slight increase in body temperature [196]. However, in some cases, the disseminated microorganisms will settle in a site where conditions are favorable for their growth; thus, bacteremia can lead to cardiovascular CDs or diabetes $[10,198]$. Alternatively, the production or the release of toxins such as exotoxins, endotoxins, bacterial proteins can enter into the bloodstream and, thus, be disseminated throughout the body, attaining organs where they cause CDs $[10,197]$. Finally, oral bacteria can induce local inflammation and the inflammatory molecules produced can diffuse in the body through the bloodstream and provoke acute and chronic inflammatory reactions at a distance from the infection site. Bacteria can also enter the bloodstream, react with specific circulating antibodies, and form macromolecular complexes that can give rise to a variety of acute and chronic inflammatory reactions at deposition sites [10,198]. The treatment of PDs leads to both a reduction in the systemic inflammatory burden and an improvement in endothelial function [199]. 


\section{- Diffusion of bacteria through the digestive pathway}

Although the mechanism is unknown oral bacteria, bacterial products and inflammatory molecules can also diffuse through the digestive tract, but they must be able to resist stomach acidity to survive and multiply in the gastrointestinal tract $[200,201]$. While the link between bacterial colonization of the intestine, intestinal inflammation and CDs has not been established, results from an observational study showed that oral bacteria can colonize and persist in the intestines, leading to activation of the immune system and chronic inflammation [202]. Oral bacteria can invade the intestinal tract directly through the esophagus, provoking intestinal dysbiosis and affecting the digestive system, leading to systemic disease [10]. Thus, several studies have reported that the passage of $P$. gingivalis through the intestine via the digestive tract is implicated in many diseases, such as colon cancer, chronic inflammatory bowel disease and diabetes. P. gingivalis induces dysbiosis by altering the innate defenses of the host and promoting inflammatory responses in phagocytic cells [203].

\section{The Association between Nutrition, Periodontal Disease and Chronic Diseases}

Our study has some limitations due to the choice of the review for developing and presenting summaries of evidence. Decisions about attributing a GRADE level are subjective but, to minimize bias, each article was assessed by two authors and we observed little disaccord between the GRADE levels attributed. We also excluded beverages (coffee, sodas, alcohol) that are modifiable risk factors, to focus the findings on nutriments and nutritional intake.

Nevertheless, this review provides strong evidence that nutrition is a common modifiable risk factor for PDs and other CDs. High-sugar, high-saturated-fat, low-polyols, low-fiber and low-polyunsaturated-fat intake cause an increased risk of PDs. This pattern of nutrients is classically found in the Western diet, which is considered as an 'unhealthy' diet that causes CVDs, diabetes and cancers. Conversely, low sugar, high fiber and high omega- 6 to omega-3 fatty acid ratio intake reduces the risk of PDs. The Mediterranean, DASH, vegetarian and Okinawa diets that correspond to these nutritional intakes are considered as 'healthy' diets, and reduce this risk of CVDs, diabetes and cancers. The role of micronutrients, such as vitamin D, E, K and magnesium, remains unclear, while others, such as vitamin A, B, C, calcium, zinc and polyphenol, have been shown to prevent PDs. Hence, Western diets that have a low intake of these latter nutriments cause PDs and Mediterranean diets, with a higher intake, lead to periodontal health [24,204]. These results are observed in specific populations. The adoption of the Mediterranean diet in a group of overweight/obese subjects led to a significant decrease in periodontal pathogens such as P. gingivalis, P. intermedia and T. denticola in the saliva [205]. The Okinawan-based nordic diet improved the general and periodontal health in diabetic patients [206]. Some evidence suggests that probiotics and prebiotics could promote good periodontal health, but more studies are required.

A bidirectional association seems to exist between nutrition/PDs and nutrition/CDs and although it has very rarely been assessed, it seems that PD or CDs could impact the nutrition. Sheiham et al. showed that a lower intake of vitamins, calcium, essential fatty acids, protein, and total calories was significantly associated with lower numbers of natural teeth [207]. An adult population with coronary artery disease and PDs were reported to have a significantly higher percentage of their total energy contribution from beans, fried food and sweets, and to eat less fruit than people without PDs [208]. Longitudinal studies with representative samples are needed to confirm these results. The studies assessing associations between PDs and nutrition have essentially focused on the potential consequences of PDs on adults' quality of life. PDs can result in clinical signs and symptoms, including tooth mobility, bleeding, gingival recession and dental loss, which have a negative impact on daily life [209]. Since PDs are a major cause of tooth loss in adults, people with PDs are at risk of multi-tooth loss, edentulism and chewing dysfunction, which will affect their nutrition, quality of life and self-esteem [210]. Poor oral health can modify food 
choices negatively, which could lead to sub-optimal nutritional condition. Hence, it is important to identify and treat periodontal and dietary problems to improve quality of life and health [43]. It has been shown that it is easier to raise awareness of the need to change eating habits in an individual with CD than in healthy people. Thus, secondary prevention has a better influence on dietary behavior than primary prevention [105]. Very few studies have analyzed the influence of CDs on dietary behaviour. In an observational study, Chong et al. (2017) concluded that the diagnosis of diabetes did not significantly change patients' diets [211]. In contrast, patients experience a reduction in their quality of life during and after cancer treatment, and due to several symptoms, these patients modify their diets [212]. However, more studies are needed to confirm these results.

Although PDs, CVDs, diabetes and cancer are all considered as CDs, they occur at different ages. World Health Organization, reported a very high prevalence of PDs in individuals aged 35 to 44 years old in 35 countries [14]. Periodontal bacteria and interdental inflammation has been reported in people aged 20 to 35 years old $[213,214]$. In contrast, the risk of CVD, diabetes and cancers increases with age. The risk of CVD is higher in men aged 55 years and women aged 65 [215]. The risk of diabetes is higher after 45 years old [216]. The risk of cancers starts to increase after 40 years of age but is highest at 65-69 years [217]. Therefore, over the life course, depending on age, a person will have a different risk of developing a CD. At first, the person will be at risk of developing periodontal disease and then, as age advances, he will be confronted with other chronic diseases such as CVDs, diabetes or cancer (Figure 4).

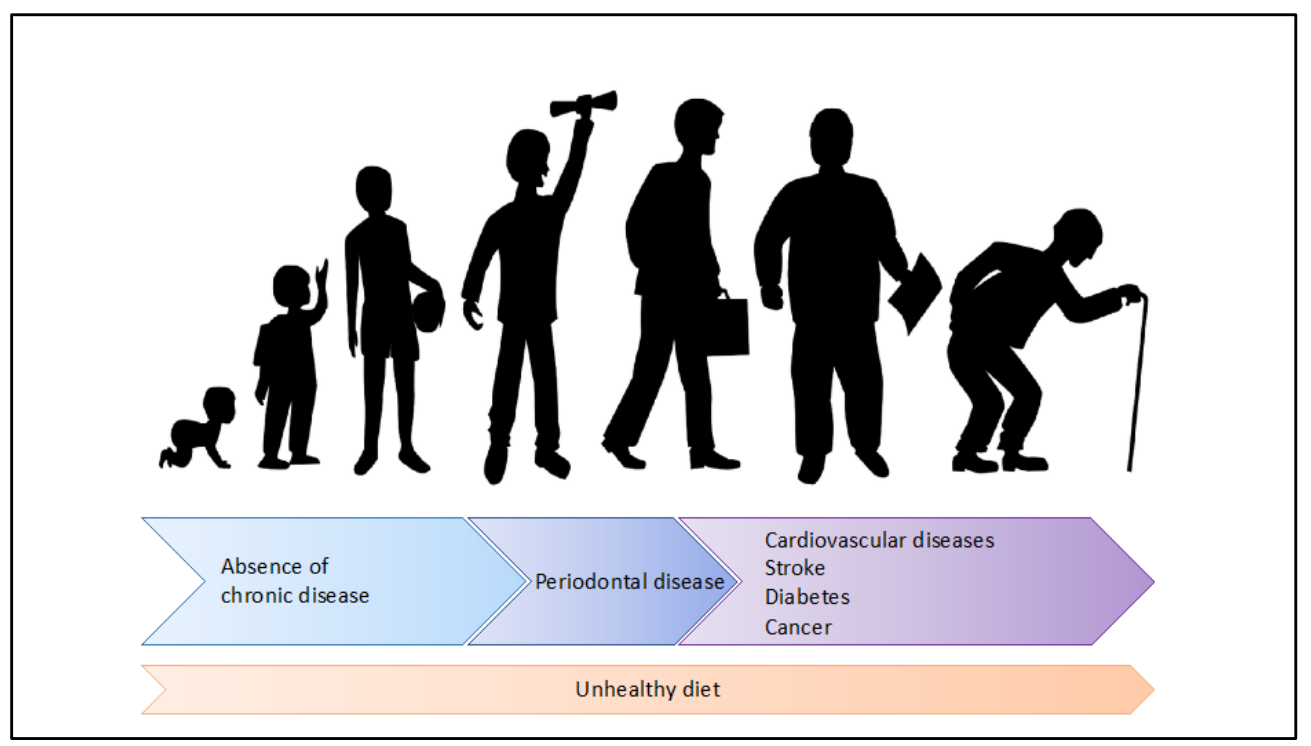

Figure 4. Nutrition as key risk factor of the periodontal disease and other chronic diseases during the life course.

Since nutrition is a risk factor for PDs and other non-communicable diseases and the risk for PDs appears early in life, it seems likely that nutritional control is the key factor for prevention because it can prevent PDs and, therefore, other main CDs. In addition, a healthy diet can contribute to the treatment of PDs and, consequently, this can help to prevent the apparition of CDs.

The results of this scoping review have implications for prevention and health promotion. First, nutritional deficiencies at certain stages of life can have short- and long-term consequences, including intergenerational effects [218]. Considering nutrition throughout life also requires an integrated offer of health and nutrition services by health care systems in all contexts [219]. Secondly, three of the most prominent noncommunicable diseases-cardiovascular disease, cancer, and diabetes-are linked by common preventable risk factors related to unhealthy diet. Therefore, action to prevent these diseases should 
focus on controlling the risk factors in an integrated manner. Several evidence-informed actions exist to address nutrition actions relevant to adolescents and adults, i.e., promotion of health across the life course and prevention and control of CDs based on an integrated risk factor approach [220]. Thirdly, a dedicated effort is required to mobilize collective action for health. PD control and public health need to take integrated approaches to health promotion and disease prevention based on common risk factors [219]. At the least, interprofessional education should be an important part of the modern educational landscape. Introducing an education program for health practitioner students can provide them with adequate knowledge, awareness, confidence, and attitude regarding oral and chronic health issues in link with the in connection with the essential nutrition knowledge [221]. It can help them in changing behavior, prevention and ongoing CDs surveillance. Therefore, future dentists, one of the largest health professions, providing the initial contact with patients in many cases, would be put in a position where they can significantly help reduce oral and chronic health diseases.

The clinical relevance of the results of these studies highlight that nutrition is a key component of PD prevention. Health care professionals should teach their patients how to adopt a healthy diet. According to our review, to prevent the onset of PD and, later, $\mathrm{CDs}$, the diet should be low in sugar and saturated fatty acid but rich in polyols, fibers, polyunsaturated acids, vitamin A, vitamin B, vitamin C, calcium and polyphenols. At the same time, they must also teach oral hygiene practices because oral hygiene is another key component of PD prevention [14]. Professional preventive measures must be based on appropriate periodontal diagnosis, as mechanical plaque removal alone is inappropriate as treatment of PD [222]. Oral hygiene should be taught very early in life because it has been shown that young adults already have a dysbiotic oral microbiota and signs of interdental inflammation that may progress to PD [213,214]. Priority should be given to the disorganization of oral biofilm, especially in the interdental spaces, as part of an individual oral prophylaxis that is delivered and controlled for each patient [223]. Prevention and control of the inflammation gingival process is a critical component for the prevention of PD. Behavioral change and risk factor control approaches should be incorporated in preventive efforts. Professional measures, including actions for themselves and for persons under their care, should be used to prevent disease and maintain quality of life. With appropriate diet and nutrition, primary prevention of many PDs and, consequently, CDs can be achieved.

While there are a number of evidence-based actions to address nutrition actions in relation to periodontal health and relevant CD prevention, the available evidence is limited in some knowledge areas. Further research could be merited in the listed areas: (i) Determining the daily quantity of each nutrient associated with periodontal health and general health; (ii) Increasing the level of evidence for the coexistence of diet with related $\mathrm{CD}$ risk factors in adolescence and adults. If an incorrect nutritional intake correlates to a state of oral disease, the inverse relationship is not proved. Compromised oral health can alter food choices and negatively impact food intake leading to suboptimal nutritional status which can lead to CDs [43]; (iii) Promoting the comprehensive integrated assessment, diagnosis, prevention and management of all forms of malnutrition on the prevention and management of PD [224]; (iv) Establishing follow-up action implementation research to help identify delivery innovations that reach and affect populations in order to achieve scale-up, health systems integration and sustainability. In particular, early interactions between different health professionals could help to understand the overall issues and the importance of interpersonal skills in the healthcare workplace. This will address the concern of low knowledge among physicians regarding oral health, the relationship between PD and systemic health.

\section{Conclusions}

In conclusion, this review gathers evidence for the potential relationship between nutrition/PDs, nutrition/CDs and PDs/CDs, providing a detailed review of key resources 
for healthy and nutritional habits. More than healthy diet habits, we synthetized the micro- and macro-nutrients that are beneficial for health. This highlights that, during his life course, an individual adopting an unhealthy diet will be at risk of periodontal disease. Later, if his eating habits remain unchanged and the PD untreated, then he will be at risk of other CDs, such as neuro- and cardio-vascular diseases, cancers and diabetes. Therefore, the PD could thus be considered as an early risk factor of the appearance of the other chronic diseases, a kind of sentry disease. In the complex multi-component setting composed of nutrition/PD/CDs, the main lesson to be taken home is the importance of common, integrated objectives and strategies for the prevention of chronic diseases, of which nutrition is the cornerstone.

Author Contributions: Conceptualization, P.M., L.F. and F.C.; methodology, L.F.; validation, P.M., L.F. and F.C.; investigation, P.M., L.F. and F.C.; writing-original draft preparation, P.M., L.F., C.D., D.B. and F.C.; writing-review and editing, P.M., L.F., D.B., C.D., A.G. and F.C. All authors have read and agreed to the published version of the manuscript.

Funding: This research received no external funding.

Data Availability Statement: No new data were created or analyzed in this study. Data sharing is not applicable to this article.

Acknowledgments: The authors acknowledge editing services from Margaret Haugh, MediCom Consult, Villeurbanne, France.

Conflicts of Interest: The authors declare no conflict of interest.

\section{References}

1. Robinson, S.M. Infant Nutrition and Lifelong Health: Current Perspectives and Future Challenges. J. Dev. Orig. Health Dis. 2015, 6, 384-389. [CrossRef]

2. Global Nutrition Policy Review 2016-2017: Country Progress in Creating Enabling Policy Environments for Promoting Healthy Diets and Nutrition. Available online: https:/ / www.who.int/publications-detail-redirect/9789241514873 (accessed on 23 October 2020).

3. Singleton, C.R.; Li, Y.; Odoms-Young, A.; Zenk, S.N.; Powell, L.M. Change in Food and Beverage Availability and Marketing Following the Introduction of a Healthy Food Financing Initiative-Supported Supermarket. Am. J. Health Promot. 2019, 33, 525-533. [CrossRef]

4. Hruby, A.; Hu, F.B. The Epidemiology of Obesity: A Big Picture. Pharmacoeconomics 2015, 33, 673-689. [CrossRef]

5. Oates, G.R.; Jackson, B.E.; Partridge, E.E.; Singh, K.P.; Fouad, M.N.; Bae, S. Sociodemographic Patterns of Chronic Disease: How the Mid-South Region Compares to the Rest of the Country. Am. J. Prev. Med. 2017, 52, S31-S39. [CrossRef]

6. Kassebaum, N.J.; Smith, A.G.C.; Bernabé, E.; Fleming, T.D.; Reynolds, A.E.; Vos, T.; Murray, C.J.L.; Marcenes, W. GBD 2015 Oral Health Collaborators Global, Regional, and National Prevalence, Incidence, and Disability-Adjusted Life Years for Oral Conditions for 195 Countries, 1990-2015: A Systematic Analysis for the Global Burden of Diseases, Injuries, and Risk Factors. J. Dent. Res. 2017, 96, 380-387. [CrossRef]

7. Nazir, M.A. Prevalence of Periodontal Disease, Its Association with Systemic Diseases and Prevention. Int. J. Health Sci. Qassim 2017, 11, 72-80.

8. Najeeb, S.; Zafar, M.S.; Khurshid, Z.; Zohaib, S.; Almas, K. The Role of Nutrition in Periodontal Health: An Update. Nutrients 2016, 8, 530. [CrossRef] [PubMed]

9. Kato, I.; Vasquez, A.; Moyerbrailean, G.; Land, S.; Djuric, Z.; Sun, J.; Lin, H.-S.; Ram, J.L. Nutritional Correlates of Human Oral Microbiome. J. Am. Coll. Nutr. 2017, 36, 88-98. [CrossRef] [PubMed]

10. Bourgeois, D.; Inquimbert, C.; Ottolenghi, L.; Carrouel, F. Periodontal Pathogens as Risk Factors of Cardiovascular Diseases, Diabetes, Rheumatoid Arthritis, Cancer, and Chronic Obstructive Pulmonary Disease-Is There Cause for Consideration? Microorganisms 2019, 7, 424. [CrossRef] [PubMed]

11. Sanz, M.; Marco Del Castillo, A.; Jepsen, S.; Gonzalez-Juanatey, J.R.; D’Aiuto, F.; Bouchard, P.; Chapple, I.; Dietrich, T.; Gotsman, I.; Graziani, F.; et al. Periodontitis and Cardiovascular Diseases: Consensus Report. J. Clin. Periodontol. 2020, 47, 268-288. [CrossRef]

12. Polak, D.; Shapira, L. An Update on the Evidence for Pathogenic Mechanisms That May Link Periodontitis and Diabetes. J. Clin. Periodontol. 2018, 45, 150-166. [CrossRef] [PubMed]

13. Nagpal, R.; Yamashiro, Y.; Izumi, Y. The Two-Way Association of Periodontal Infection with Systemic Disorders: An Overview. Mediat. Inflamm. 2015, 2015, 793898. [CrossRef] [PubMed]

14. Petersen, P.E.; Bourgeois, D.; Ogawa, H.; Estupinan-Day, S.; Ndiaye, C. The Global Burden of Oral Diseases and Risks to Oral Health. Bull. World Health Organ. 2005, 83, 661-669. [CrossRef]

15. Sucharew, H.; Macaluso, M. Progress Notes: Methods for Research Evidence Synthesis: The Scoping Review Approach. J. Hosp. Med. 2019, 14, 416-418. [CrossRef] [PubMed] 
16. Arksey, H.; O’Malley, L. Scoping Studies: Towards a Methodological Framework. Int. J. Soc. Res. Methodol. 2005, 8, 19-32. [CrossRef]

17. Munn, Z.; Peters, M.D.J.; Stern, C.; Tufanaru, C.; McArthur, A.; Aromataris, E. Systematic Review or Scoping Review? Guidance for Authors When Choosing between a Systematic or Scoping Review Approach. BMC Med. Res. Methodol. 2018, 18. [CrossRef]

18. Burns, P.B.; Rohrich, R.J.; Chung, K.C. The Levels of Evidence and Their Role in Evidence-Based Medicine. Plast Reconstr. Surg. 2011, 128, 305-310. [CrossRef]

19. What Is GRADE? I BMJ Best Practice. Available online: https://bestpractice.bmj.com/info/toolkit/learn-ebm/what-is-grade/ (accessed on 23 October 2020).

20. Balshem, H.; Helfand, M.; Schünemann, H.J.; Oxman, A.D.; Kunz, R.; Brozek, J.; Vist, G.E.; Falck-Ytter, Y.; Meerpohl, J.; Norris, S.; et al. GRADE Guidelines: 3. Rating the Quality of Evidence. J. Clin. Epidemiol. 2011, 64, 401-406. [CrossRef]

21. Slavin, J.; Carlson, J. Carbohydrates. Adv. Nutr. 2014, 5, 760-761. [CrossRef]

22. Feinman, R.D.; Pogozelski, W.K.; Astrup, A.; Bernstein, R.K.; Fine, E.J.; Westman, E.C.; Accurso, A.; Frassetto, L.; Gower, B.A.; McFarlane, S.I.; et al. Dietary Carbohydrate Restriction as the First Approach in Diabetes Management: Critical Review and Evidence Base. Nutrition 2015, 31, 1-13. [CrossRef]

23. Lula, E.C.O.; Ribeiro, C.C.C.; Hugo, F.N.; Alves, C.M.C.; Silva, A.A.M. Added Sugars and Periodontal Disease in Young Adults: An Analysis of NHANES III Data. Am. J. Clin. Nutr. 2014, 100, 1182-1187. [CrossRef] [PubMed]

24. Woelber, J.P.; Bremer, K.; Vach, K.; König, D.; Hellwig, E.; Ratka-Krüger, P.; Al-Ahmad, A.; Tennert, C. An Oral Health Optimized Diet Can Reduce Gingival and Periodontal Inflammation in Humans-A Randomized Controlled Pilot Study. BMC Oral Health 2017, 17. [CrossRef] [PubMed]

25. Bosma-den Boer, M.M.; Van Wetten, M.-L.; Pruimboom, L. Chronic Inflammatory Diseases Are Stimulated by Current Lifestyle: How Diet, Stress Levels and Medication Prevent Our Body from Recovering. Nutr. Metab. 2012, 9, 32. [CrossRef] [PubMed]

26. Adler, C.J.; Dobney, K.; Weyrich, L.S.; Kaidonis, J.; Walker, A.W.; Haak, W.; Bradshaw, C.J.A.; Townsend, G.; Sołtysiak, A.; Alt, K.W.; et al. Sequencing Ancient Calcified Dental Plaque Shows Changes in Oral Microbiota with Dietary Shifts of the Neolithic and Industrial Revolutions. Nat. Genet. 2013, 45, 450-455. [CrossRef] [PubMed]

27. Liu, J.; Jiang, Y.; Mao, J.; Gu, B.; Liu, H.; Fang, B. High Levels of Glucose Induces a Dose-Dependent Apoptosis in Human Periodontal Ligament Fibroblasts by Activating Caspase-3 Signaling Pathway. Appl. Biochem. Biotechnol. 2013, 170, $1458-1471$. [CrossRef]

28. Park, E.; Na, H.S.; Kim, S.M.; Wallet, S.; Cha, S.; Chung, J. Xylitol, an Anticaries Agent, Exhibits Potent Inhibition of Inflammatory Responses in Human THP-1-Derived Macrophages Infected with Porphyromonas Gingivalis. J. Periodontol. 2014, 85, e212-e223. [CrossRef]

29. Keukenmeester, R.S.; Slot, D.E.; Rosema, N.A.M.; Van Loveren, C.; Van der Weijden, G.A. Effects of Sugar-Free Chewing Gum Sweetened with Xylitol or Maltitol on the Development of Gingivitis and Plaque: A Randomized Clinical Trial. Int. J. Dent. Hyg. 2014, 12, 238-244. [CrossRef]

30. Kim, S.; Park, M.H.; Song, Y.R.; Na, H.S.; Chung, J. Aggregatibacter Actinomycetemcomitans-Induced AIM2 Inflammasome Activation Is Suppressed by Xylitol in Differentiated THP-1 Macrophages. J. Periodontol. 2016, 87, e116-e126. [CrossRef]

31. Bradshaw, D.J.; Marsh, P.D. Effect of Sugar Alcohols on the Composition and Metabolism of a Mixed Culture of Oral Bacteria Grown in a Chemostat. Caries Res. 1994, 28, 251-256. [CrossRef]

32. Salazar, C.R.; Laniado, N.; Mossavar-Rahmani, Y.; Borrell, L.N.; Qi, Q.; Sotres-Alvarez, D.; Morse, D.E.; Singer, R.H.; Kaplan, R.C.; Badner, V.; et al. Better Diet Quality Is Associated with Lower Odds of Severe Periodontitis in US Hispanics/Latinos. J. Clin. Periodontol. 2018, 45, 780-790. [CrossRef]

33. Fujii, H.; Iwase, M.; Ohkuma, T.; Ogata-Kaizu, S.; Ide, H.; Kikuchi, Y.; Idewaki, Y.; Joudai, T.; Hirakawa, Y.; Uchida, K.; et al. Impact of Dietary Fiber Intake on Glycemic Control, Cardiovascular Risk Factors and Chronic Kidney Disease in Japanese Patients with Type 2 Diabetes Mellitus: The Fukuoka Diabetes Registry. Nutr. J. 2013, 12, 159. [CrossRef] [PubMed]

34. Forouhi, N.G.; Krauss, R.M.; Taubes, G.; Willett, W. Dietary Fat and Cardiometabolic Health: Evidence, Controversies, and Consensus for Guidance. BMJ 2018, 361, k2139. [CrossRef] [PubMed]

35. Hamasaki, T.; Kitamura, M.; Kawashita, Y.; Ando, Y.; Saito, T. Periodontal Disease and Percentage of Calories from Fat Using National Data. J. Periodont. Res. 2017, 52, 114-121. [CrossRef] [PubMed]

36. Milward, M.R.; Chapple, I. The Role of Diet in Periodontal Disease. Clin. Dent. Health 2013, 52, $18-21$.

37. Varela-López, A.; Giampieri, F.; Bullón, P.; Battino, M.; Quiles, J.L. Role of Lipids in the Onset, Progression and Treatment of Periodontal Disease. A Systematic Review of Studies in Humans. Int. J. Mol. Sci. 2016, 17, 1202. [CrossRef]

38. Serhan, C.N.; Chiang, N.; Dalli, J. The Resolution Code of Acute Inflammation: Novel pro-Resolving Lipid Mediators in Resolution. Semin. Immunol. 2015, 27, 200-215. [CrossRef]

39. Hasturk, H.; Kantarci, A.; Van Dyke, T.E. Paradigm Shift in the Pharmacological Management of Periodontal Diseases. Front. Oral Biol. 2012, 15, 160-176. [CrossRef]

40. El-Sharkawy, H.; Aboelsaad, N.; Eliwa, M.; Darweesh, M.; Alshahat, M.; Kantarci, A.; Hasturk, H.; Van Dyke, T.E. Adjunctive Treatment of Chronic Periodontitis with Daily Dietary Supplementation with Omega-3 Fatty Acids and Low-Dose Aspirin. J. Periodontol. 2010, 81, 1635-1643. [CrossRef]

41. Elkhouli, A.M. The Efficacy of Host Response Modulation Therapy (Omega-3 plus Low-Dose Aspirin) as an Adjunctive Treatment of Chronic Periodontitis (Clinical and Biochemical Study). J. Periodont. Res. 2011, 46, 261-268. [CrossRef] 
42. Cagetti, M.G.; Wolf, T.G.; Tennert, C.; Camoni, N.; Lingström, P.; Campus, G. The Role of Vitamins in Oral Health. A Systematic Review and Meta-Analysis. Int. J. Environ. Res. Public Health 2020, 17, 938. [CrossRef]

43. Gondivkar, S.M.; Gadbail, A.R.; Gondivkar, R.S.; Sarode, S.C.; Sarode, G.S.; Patil, S.; Awan, K.H. Nutrition and Oral Health. Dis. Mon. 2019, 65, 147-154. [CrossRef] [PubMed]

44. Dommisch, H.; Kuzmanova, D.; Jönsson, D.; Grant, M.; Chapple, I. Effect of Micronutrient Malnutrition on Periodontal Disease and Periodontal Therapy. Periodontology 2000 2018, 78, 129-153. [CrossRef] [PubMed]

45. Dodington, D.W.; Fritz, P.C.; Sullivan, P.J.; Ward, W.E. Higher Intakes of Fruits and Vegetables, $\beta$-Carotene, Vitamin C, $\alpha$-Tocopherol, EPA, and DHA Are Positively Associated with Periodontal Healing after Nonsurgical Periodontal Therapy in Nonsmokers but Not in Smokers. J. Nutr. 2015, 145, 2512-2519. [CrossRef]

46. Zong, G.; Holtfreter, B.; Scott, A.E.; Völzke, H.; Petersmann, A.; Dietrich, T.; Newson, R.S.; Kocher, T. Serum Vitamin B12 Is Inversely Associated with Periodontal Progression and Risk of Tooth Loss: A Prospective Cohort Study. J. Clin. Periodontol. 2016, 43, 2-9. [CrossRef] [PubMed]

47. Shimabukuro, Y.; Nakayama, Y.; Ogata, Y.; Tamazawa, K.; Shimauchi, H.; Nishida, T.; Ito, K.; Chikazawa, T.; Kataoka, S.; Murakami, S. Effects of an Ascorbic Acid-Derivative Dentifrice in Patients with Gingivitis: A Double-Masked, Randomized, Controlled Clinical Trial. J. Periodontol. 2015, 86, 27-35. [CrossRef]

48. Schwalfenberg, G.K.; Genuis, S.J. Vitamin D, Essential Minerals, and Toxic Elements: Exploring Interactions between Nutrients and Toxicants in Clinical Medicine. Sci. World J. 2015, 2015. [CrossRef]

49. Antonoglou, G.N.; Knuuttila, M.; Niemelä, O.; Raunio, T.; Karttunen, R.; Vainio, O.; Hedberg, P.; Ylöstalo, P.; Tervonen, T. Low Serum Level of 1,25(OH)2 D Is Associated with Chronic Periodontitis. J. Periodont. Res. 2015, 50, 274-280. [CrossRef]

50. Bashutski, J.D.; Eber, R.M.; Kinney, J.S.; Benavides, E.; Maitra, S.; Braun, T.M.; Giannobile, W.V.; McCauley, L.K. The Impact of Vitamin D Status on Periodontal Surgery Outcomes. J. Dent. Res. 2011, 90, 1007-1012. [CrossRef]

51. Stein, S.H.; Tipton, D.A. Vitamin D and Its Impact on Oral Health-An Update. J. Tenn. Dent. Assoc. 2011, 91, 30-33.

52. Lee, H.-J.; Je, D.-I.; Won, S.-J.; Paik, D.-I.; Bae, K.-H. Association between Vitamin D Deficiency and Periodontal Status in Current Smokers. Community Dent. Oral Epidemiol. 2015, 43, 471-478. [CrossRef]

53. Scientific Opinion on Dietary Reference Values for Vitamin A. EFSA J. 2015, 13, 4028. [CrossRef]

54. Pfeiffer, C.M.; Sternberg, M.R.; Schleicher, R.L.; Rybak, M.E. Dietary Supplement Use and Smoking Are Important Correlates of Biomarkers of Water-Soluble Vitamin Status after Adjusting for Sociodemographic and Lifestyle Variables in a Representative Sample of U.S. Adults. J. Nutr. 2013, 143, 957S-965S. [CrossRef] [PubMed]

55. Zong, G.; Scott, A.E.; Griffiths, H.R.; Zock, P.L.; Dietrich, T.; Newson, R.S. Serum $\alpha$-Tocopherol Has a Nonlinear Inverse Association with Periodontitis among US Adults. J. Nutr. 2015, 145, 893-899. [CrossRef] [PubMed]

56. Gröber, U.; Reichrath, J.; Holick, M.F.; Kisters, K. Vitamin K: An Old Vitamin in a New Perspective. Dermatoendocrinology 2014, 6, e968490. [CrossRef]

57. Aral, K.; Alkan, B.A.; Saraymen, R.; Yay, A.; Şen, A.; Önder, G.Ö. Therapeutic Effects of Systemic Vitamin K2 and Vitamin D3 on Gingival Inflammation and Alveolar Bone in Rats with Experimentally Induced Periodontitis. J. Periodontol. 2015, 86, 666-673. [CrossRef]

58. Adegboye, A.R.; Boucher, B.J.; Kongstad, J.; Fiehn, N.-E.; Christensen, L.B.; Heitmann, B.L. Calcium, Vitamin D, Casein and Whey Protein Intakes and Periodontitis among Danish Adults. Public Health Nutr. 2016, 19, 503-510. [CrossRef]

59. Tanaka, K.; Miyake, Y.; Okubo, H.; Hanioka, T.; Sasaki, S.; Miyatake, N.; Arakawa, M. Calcium Intake Is Associated with Decreased Prevalence of Periodontal Disease in Young Japanese Women. Nutr. J. 2014, 13, 109. [CrossRef]

60. Staudte, H.; Kranz, S.; Völpel, A.; Schütze, J.; Sigusch, B.W. Comparison of Nutrient Intake between Patients with Periodontitis and Healthy Subjects. Quintessence Int. 2012, 43, 907-916.

61. Chakraborty, S.; Tewari, S.; Sharma, R.K.; Narula, S.C.; Ghalaut, P.S.; Ghalaut, V. Impact of Iron Deficiency Anemia on Chronic Periodontitis and Superoxide Dismutase Activity: A Cross-Sectional Study. J. Periodontal. Implant. Sci. 2014, 44, 57-64. [CrossRef]

62. Olza, J.; Aranceta-Bartrina, J.; González-Gross, M.; Ortega, R.M.; Serra-Majem, L.; Varela-Moreiras, G.; Gil, Á. Reported Dietary Intake and Food Sources of Zinc, Selenium, and Vitamins A, E and C in the Spanish Population: Findings from the ANIBES Study. Nutrients 2017, 9, 697. [CrossRef]

63. Rostan, E.F.; DeBuys, H.V.; Madey, D.L.; Pinnell, S.R. Evidence Supporting Zinc as an Important Antioxidant for Skin. Int. J. Dermatol. 2002, 41, 606-611. [CrossRef] [PubMed]

64. Thomas, B.; Kumari, S.; Ramitha, K.; Ashwini Kumari, M.B. Comparative Evaluation of Micronutrient Status in the Serum of Diabetes Mellitus Patients and Healthy Individuals with Periodontitis. J. Indian Soc. Periodontol. 2010, 14, 46-49. [CrossRef] [PubMed]

65. Thomas, B.; Ramesh, A.; Suresh, S.; Prasad, B.R. A Comparative Evaluation of Antioxidant Enzymes and Selenium in the Serum of Periodontitis Patients with Diabetes Mellitus Type 2. Contemp. Clin. Dent. 2013, 4, 176-180. [CrossRef] [PubMed]

66. Silva, R.F.M.; Pogačnik, L. Polyphenols from Food and Natural Products: Neuroprotection and Safety. Antioxidants 2020, 9, 61. [CrossRef] [PubMed]

67. Kote, S.; Kote, S.; Nagesh, L. Effect of Pomegranate Juice on Dental Plaque Microorganisms (Streptococci and Lactobacilli). Anc. Sci. Life 2011, 31, 49-51.

68. Bhatia, M.; Urolagin, S.S.; Pentyala, K.B.; Urolagin, S.B.; KB, M.; Bhoi, S. Novel Therapeutic Approach for the Treatment of Periodontitis by Curcumin. J. Clin. Diagn Res. 2014, 8, ZC65-ZC69. [CrossRef] 
69. Chapple, I.L.C.; Milward, M.R.; Ling-Mountford, N.; Weston, P.; Carter, K.; Askey, K.; Dallal, G.E.; De Spirt, S.; Sies, H.; Patel, D.; et al. Adjunctive Daily Supplementation with Encapsulated Fruit, Vegetable and Berry Juice Powder Concentrates and Clinical Periodontal Outcomes: A Double-Blind RCT. J. Clin. Periodontol. 2012, 39, 62-72. [CrossRef]

70. Grover, S.; Tewari, S.; Sharma, R.K.; Singh, G.; Yadav, A.; Naula, S.C. Effect of Subgingivally Delivered 10\% Emblica Officinalis Gel as an Adjunct to Scaling and Root Planing in the Treatment of Chronic Periodontitis-A Randomized Placebo-Controlled Clinical Trial. Phytother. Res. 2016, 30, 956-962. [CrossRef]

71. Hrishi, T.S.; Kundapur, P.P.; Naha, A.; Thomas, B.S.; Kamath, S.; Bhat, G.S. Effect of Adjunctive Use of Green Tea Dentifrice in Periodontitis Patients-A Randomized Controlled Pilot Study. Int. J. Dent. Hyg. 2016, 14, 178-183. [CrossRef]

72. Chava, V.K.; Vedula, B.D. Thermo-Reversible Green Tea Catechin Gel for Local Application in Chronic Periodontitis: A 4-Week Clinical Trial. J. Periodontol. 2013, 84, 1290-1296. [CrossRef]

73. Isolauri, E.; Kirjavainen, P.V.; Salminen, S. Probiotics: A Role in the Treatment of Intestinal Infection and Inflammation? Gut 2002, 50 (Suppl. 3), III54-III59. [CrossRef] [PubMed]

74. Matsubara, V.H.; Bandara, H.M.H.N.; Ishikawa, K.H.; Mayer, M.P.A.; Samaranayake, L.P. The Role of Probiotic Bacteria in Managing Periodontal Disease: A Systematic Review. Expert Rev. Anti. Infect. Ther. 2016, 14, 643-655. [CrossRef] [PubMed]

75. Morales, A.; Bravo-Bown, J.; Bedoya, J.; Gamonal, J. Probiotics and Periodontal Diseases. Insights Var. Asp. Oral Health 2017. [CrossRef]

76. Gibson, G.R.; Roberfroid, M.B. Dietary Modulation of the Human Colonic Microbiota: Introducing the Concept of Prebiotics. J. Nutr. 1995, 125, 1401-1412. [CrossRef] [PubMed]

77. Chandra, R.V.; Swathi, T.; Reddy, A.A.; Chakravarthy, Y.; Nagarajan, S.; Naveen, A. Effect of a Locally Delivered ProbioticPrebiotic Mixture as an Adjunct to Scaling and Root Planing in the Management of Chronic Periodontitis. J. Int. Acad. Periodontol. 2016, 18, 67-75. [PubMed]

78. Willcox, D.C.; Scapagnini, G.; Willcox, B.J. Healthy Aging Diets Other than the Mediterranean: A Focus on the Okinawan Diet. Mech. Ageing Dev. 2014, 136-137, 148-162. [CrossRef] [PubMed]

79. Statovci, D.; Aguilera, M.; MacSharry, J.; Melgar, S. The Impact of Western Diet and Nutrients on the Microbiota and Immune Response at Mucosal Interfaces. Front. Immunol. 2017, 8, 838. [CrossRef]

80. Fabiani, R.; Minelli, L.; Bertarelli, G.; Bacci, S. A Western Dietary Pattern Increases Prostate Cancer Risk: A Systematic Review and Meta-Analysis. Nutrients 2016, 8, 626. [CrossRef]

81. Rodríguez-Monforte, M.; Flores-Mateo, G.; Sánchez, E. Dietary Patterns and CVD: A Systematic Review and Meta-Analysis of Observational Studies. Br. J. Nutr. 2015, 114, 1341-1359. [CrossRef]

82. AlJehani, Y.A. Risk Factors of Periodontal Disease: Review of the Literature. Int. J. Dent. 2014, 2014. [CrossRef]

83. Oikonomou, E.; Psaltopoulou, T.; Georgiopoulos, G.; Siasos, G.; Kokkou, E.; Antonopoulos, A.; Vogiatzi, G.; Tsalamandris, S.; Gennimata, V.; Papanikolaou, A.; et al. Western Dietary Pattern Is Associated With Severe Coronary Artery Disease. Angiology 2018, 69, 339-346. [CrossRef] [PubMed]

84. Srour, B.; Fezeu, L.K.; Kesse-Guyot, E.; Allès, B.; Méjean, C.; Andrianasolo, R.M.; Chazelas, E.; Deschasaux, M.; Hercberg, S.; Galan, P.; et al. Ultra-Processed Food Intake and Risk of Cardiovascular Disease: Prospective Cohort Study (NutriNet-Santé). BMJ 2019, 365, 11451. [CrossRef] [PubMed]

85. Ha, S.K. Dietary Salt Intake and Hypertension. Electrolyte Blood Press. 2014, 12, 7-18. [CrossRef] [PubMed]

86. He, F.J.; Pombo-Rodrigues, S.; Macgregor, G.A. Salt Reduction in England from 2003 to 2011: Its Relationship to Blood Pressure, Stroke and Ischaemic Heart Disease Mortality. BMJ Open 2014, 4, e004549. [CrossRef]

87. Beigrezaei, S.; Ghiasvand, R.; Feizi, A.; Iraj, B. Relationship between Dietary Patterns and Incidence of Type 2 Diabetes. Int. J. Prev. Med. 2019, 10, 122. [CrossRef]

88. Nagao, M.; Asai, A.; Sugihara, H.; Oikawa, S. Fat Intake and the Development of Type 2 Diabetes. Endocr. J. 2015, 62, 561-572. [CrossRef]

89. Rippe, J.M.; Angelopoulos, T.J. Relationship between Added Sugars Consumption and Chronic Disease Risk Factors: Current Understanding. Nutrients 2016, 8, 697. [CrossRef]

90. Brennan, S.F.; Cantwell, M.M.; Cardwell, C.R.; Velentzis, L.S.; Woodside, J.V. Dietary Patterns and Breast Cancer Risk: A Systematic Review and Meta-Analysis. Am. J. Clin. Nutr. 2010, 91, 1294-1302. [CrossRef]

91. Xiao, Y.; Xia, J.; Li, L.; Ke, Y.; Cheng, J.; Xie, Y.; Chu, W.; Cheung, P.; Kim, J.H.; Colditz, G.A.; et al. Associations between Dietary Patterns and the Risk of Breast Cancer: A Systematic Review and Meta-Analysis of Observational Studies. Breast Cancer Res. 2019, 21, 16. [CrossRef]

92. Liu, R.; Pei, Q.; Shou, T.; Zhang, W.; Hu, J.; Li, W. Apoptotic Effect of Green Synthesized Gold Nanoparticles from Curcuma Wenyujin Extract against Human Renal Cell Carcinoma A498 Cells. Int. J. Nanomed. 2019, 14, 4091-4103. [CrossRef]

93. Sun, Y.; Li, Z.; Li, J.; Li, Z.; Han, J. A Healthy Dietary Pattern Reduces Lung Cancer Risk: A Systematic Review and Meta-Analysis. Nutrients 2016, 8, 134. [CrossRef] [PubMed]

94. Magalhães, B.; Peleteiro, B.; Lunet, N. Dietary Patterns and Colorectal Cancer: Systematic Review and Meta-Analysis. Eur. J. Cancer Prev. 2012, 21, 15-23. [CrossRef] [PubMed]

95. Feng, Y.-L.; Shu, L.; Zheng, P.-F.; Zhang, X.-Y.; Si, C.-J.; Yu, X.-L.; Gao, W.; Zhang, L. Dietary Patterns and Colorectal Cancer Risk: A Meta-Analysis. Eur. J. Cancer Prev. 2017, 26, 201-211. [CrossRef] [PubMed] 
96. Bertuccio, P.; Rosato, V.; Andreano, A.; Ferraroni, M.; Decarli, A.; Edefonti, V.; La Vecchia, C. Dietary Patterns and Gastric Cancer Risk: A Systematic Review and Meta-Analysis. Ann. Oncol. 2013, 24, 1450-1458. [CrossRef]

97. Jalilpiran, Y.; Dianatinasab, M.; Zeighami, S.; Bahmanpour, S.; Ghiasvand, R.; Mohajeri, S.A.R.; Faghih, S. Western Dietary Pattern, But Not Mediterranean Dietary Pattern, Increases the Risk of Prostate Cancer. Nutr. Cancer 2018, 70, 851-859. [CrossRef]

98. Matsushita, M.; Fujita, K.; Nonomura, N. Influence of Diet and Nutrition on Prostate Cancer. Int. J. Mol. Sci. 2020, 21, 1447. [CrossRef]

99. Bouvard, V.; Loomis, D.; Guyton, K.Z.; Grosse, Y.; Ghissassi, F.E.; Benbrahim-Tallaa, L.; Guha, N.; Mattock, H.; Straif, K. International Agency for Research on Cancer Monograph Working Group Carcinogenicity of Consumption of Red and Processed Meat. Lancet Oncol. 2015, 16, 1599-1600. [CrossRef]

100. Fiolet, T.; Srour, B.; Sellem, L.; Kesse-Guyot, E.; Allès, B.; Méjean, C.; Deschasaux, M.; Fassier, P.; Latino-Martel, P.; Beslay, M.; et al. Consumption of Ultra-Processed Foods and Cancer Risk: Results from NutriNet-Santé Prospective Cohort. BMJ 2018, 360, k322. [CrossRef]

101. Bylsma, L.C.; Alexander, D.D. A Review and Meta-Analysis of Prospective Studies of Red and Processed Meat, Meat Cooking Methods, Heme Iron, Heterocyclic Amines and Prostate Cancer. Nutr. J. 2015, 14, 125. [CrossRef]

102. Davis, C.; Bryan, J.; Hodgson, J.; Murphy, K. Definition of the Mediterranean Diet; A Literature Review. Nutrients 2015, 7, 9139-9153. [CrossRef]

103. Tsigalou, C.; Konstantinidis, T.; Paraschaki, A.; Stavropoulou, E.; Voidarou, C.; Bezirtzoglou, E. Mediterranean Diet as a Tool to Combat Inflammation and Chronic Diseases. An Overview. Biomedicines 2020, 8, 201. [CrossRef] [PubMed]

104. Schulze, M.B.; Martínez-González, M.A.; Fung, T.T.; Lichtenstein, A.H.; Forouhi, N.G. Food Based Dietary Patterns and Chronic Disease Prevention. BMJ 2018, 361, k2396. [CrossRef] [PubMed]

105. Kimokoti, R.W.; Millen, B.E. Nutrition for the Prevention of Chronic Diseases. Med. Clin. North Am. 2016, 100, 1185-1198. [CrossRef] [PubMed]

106. Galbete, C.; Schwingshackl, L.; Schwedhelm, C.; Boeing, H.; Schulze, M.B. Evaluating Mediterranean Diet and Risk of Chronic Disease in Cohort Studies: An Umbrella Review of Meta-Analyses. Eur. J. Epidemiol. 2018, 33, 909-931. [CrossRef]

107. Paterson, K.E.; Myint, P.K.; Jennings, A.; Bain, L.K.M.; Lentjes, M.A.H.; Khaw, K.-T.; Welch, A.A. Mediterranean Diet Reduces Risk of Incident Stroke in a Population With Varying Cardiovascular Disease Risk Profiles. Stroke 2018, 2415-2420. [CrossRef]

108. Sikic, J.; Stipcevic, M.; Vrazic, H.; Cerkez Habek, J.; Margetic, E.; Gulin, D. Nutrition in Primary and Secondary Prevention of Cardiovascular Risk in the Continental and Mediterranean Regions of Croatia. BMC Cardiovasc. Disord. 2017, 17, 247. [CrossRef]

109. Aridi, Y.S.; Walker, J.L.; Roura, E.; Wright, O.R.L. Adherence to the Mediterranean Diet and Chronic Disease in Australia: National Nutrition and Physical Activity Survey Analysis. Nutrients 2020, 12, 1251. [CrossRef]

110. Hernáez, Á.; Castañer, O.; Elosua, R.; Pintó, X.; Estruch, R.; Salas-Salvadó, J.; Corella, D.; Arós, F.; Serra-Majem, L.; Fiol, M.; et al. Mediterranean Diet Improves High-Density Lipoprotein Function in High-Cardiovascular-Risk Individuals: A Randomized Controlled Trial. Circulation 2017, 135, 633-643. [CrossRef]

111. Sureda, A.; Bibiloni, M.D.M.; Julibert, A.; Bouzas, C.; Argelich, E.; Llompart, I.; Pons, A.; Tur, J.A. Adherence to the Mediterranean Diet and Inflammatory Markers. Nutrients 2018, 10, 62. [CrossRef]

112. Galbete, C.; Kröger, J.; Jannasch, F.; Iqbal, K.; Schwingshackl, L.; Schwedhelm, C.; Weikert, C.; Boeing, H.; Schulze, M.B. Nordic Diet, Mediterranean Diet, and the Risk of Chronic Diseases: The EPIC-Potsdam Study. BMC Med. 2018, 16, 99. [CrossRef]

113. Jannasch, F.; Kröger, J.; Schulze, M.B. Dietary Patterns and Type 2 Diabetes: A Systematic Literature Review and Meta-Analysis of Prospective Studies. J. Nutr. 2017, 147, 1174-1182. [CrossRef] [PubMed]

114. Schwingshackl, L.; Missbach, B.; König, J.; Hoffmann, G. Adherence to a Mediterranean Diet and Risk of Diabetes: A Systematic Review and Meta-Analysis. Public Health Nutr. 2015, 18, 1292-1299. [CrossRef] [PubMed]

115. Salas-Salvadó, J.; Bulló, M.; Estruch, R.; Ros, E.; Covas, M.-I.; Ibarrola-Jurado, N.; Corella, D.; Arós, F.; Gómez-Gracia, E.; Ruiz-Gutiérrez, V.; et al. Prevention of Diabetes with Mediterranean Diets: A Subgroup Analysis of a Randomized Trial. Ann. Intern. Med. 2014, 160, 1-10. [CrossRef] [PubMed]

116. Martín-Peláez, S.; Fito, M.; Castaner, O. Mediterranean Diet Effects on Type 2 Diabetes Prevention, Disease Progression, and Related Mechanisms. A Review. Nutrients 2020, 12, 2236. [CrossRef] [PubMed]

117. Schwingshackl, L.; Hoffmann, G. Does a Mediterranean-Type Diet Reduce Cancer Risk? Curr. Nutr. Rep. 2016, 5, 9-17. [CrossRef]

118. Filomeno, M.; Bosetti, C.; Garavello, W.; Levi, F.; Galeone, C.; Negri, E.; La Vecchia, C. The Role of a Mediterranean Diet on the Risk of Oral and Pharyngeal Cancer. Br. J. Cancer 2014, 111, 981-986. [CrossRef]

119. Bosetti, C.; Turati, F.; Dal Pont, A.; Ferraroni, M.; Polesel, J.; Negri, E.; Serraino, D.; Talamini, R.; La Vecchia, C.; Zeegers, M.P. The Role of Mediterranean Diet on the Risk of Pancreatic Cancer. Br. J. Cancer 2013, 109, 1360-1366. [CrossRef]

120. Giacosa, A.; Barale, R.; Bavaresco, L.; Gatenby, P.; Gerbi, V.; Janssens, J.; Johnston, B.; Kas, K.; La Vecchia, C.; Mainguet, P.; et al. Cancer Prevention in Europe: The Mediterranean Diet as a Protective Choice. Eur. J. Cancer Prev. 2013, 22, 90-95. [CrossRef]

121. Bamia, C.; Lagiou, P.; Buckland, G.; Grioni, S.; Agnoli, C.; Taylor, A.J.; Dahm, C.C.; Overvad, K.; Olsen, A.; Tjønneland, A.; et al. Mediterranean Diet and Colorectal Cancer Risk: Results from a European Cohort. Eur. J. Epidemiol. 2013, 28, 317-328. [CrossRef]

122. Bravi, F.; Spei, M.-E.; Polesel, J.; Di Maso, M.; Montella, M.; Ferraroni, M.; Serraino, D.; Libra, M.; Negri, E.; La Vecchia, C.; et al. Mediterranean Diet and Bladder Cancer Risk in Italy. Nutrients 2018, 10, 1061. [CrossRef]

123. Mentella, M.C.; Scaldaferri, F.; Ricci, C.; Gasbarrini, A.; Miggiano, G.A.D. Cancer and Mediterranean Diet: A Review. Nutrients 2019, 11, 2059. [CrossRef] [PubMed] 
124. Grosso, G.; Buscemi, S.; Galvano, F.; Mistretta, A.; Marventano, S.; La Vela, V.; Drago, F.; Gangi, S.; Basile, F.; Biondi, A. Mediterranean Diet and Cancer: Epidemiological Evidence and Mechanism of Selected Aspects. BMC Surg. 2013, 13 (Suppl. 2), S14. [CrossRef] [PubMed]

125. Divella, R.; Daniele, A.; Savino, E.; Paradiso, A. Anticancer Effects of Nutraceuticals in the Mediterranean Diet: An Epigenetic Diet Model. Cancer Genom. Proteom. 2020, 17, 335-350. [CrossRef] [PubMed]

126. Amor, S.; Châlons, P.; Aires, V.; Delmas, D. Polyphenol Extracts from Red Wine and Grapevine: Potential Effects on Cancers. Diseases 2018, 6, 106. [CrossRef] [PubMed]

127. Gavrilova, N.S.; Gavrilov, L.A. Comments on Dietary Restriction, Okinawa Diet and Longevity. Gerontology 2012, 58, 221-223. [CrossRef]

128. Chiavaroli, L.; Viguiliouk, E.; Nishi, S.K.; Blanco Mejia, S.; Rahelić, D.; Kahleová, H.; Salas-Salvadó, J.; Kendall, C.W.; Sievenpiper, J.L. DASH Dietary Pattern and Cardiometabolic Outcomes: An Umbrella Review of Systematic Reviews and Meta-Analyses. Nutrients 2019, 11, 338. [CrossRef]

129. Ali Mohsenpour, M.; Fallah-Moshkani, R.; Ghiasvand, R.; Khosravi-Boroujeni, H.; Mehdi Ahmadi, S.; Brauer, P.; Salehi-Abargouei, A. Adherence to Dietary Approaches to Stop Hypertension (DASH)-Style Diet and the Risk of Cancer: A Systematic Review and Meta-Analysis of Cohort Studies. J. Am. Coll. Nutr. 2019, 38, 513-525. [CrossRef]

130. Shirani, F.; Salehi-Abargouei, A.; Azadbakht, L. Effects of Dietary Approaches to Stop Hypertension (DASH) Diet on Some Risk for Developing Type 2 Diabetes: A Systematic Review and Meta-Analysis on Controlled Clinical Trials. Nutrition 2013, 29 , 939-947. [CrossRef]

131. Salehi-Abargouei, A.; Maghsoudi, Z.; Shirani, F.; Azadbakht, L. Effects of Dietary Approaches to Stop Hypertension (DASH)Style Diet on Fatal or Nonfatal Cardiovascular Diseases-Incidence: A Systematic Review and Meta-Analysis on Observational Prospective Studies. Nutrition 2013, 29, 611-618. [CrossRef]

132. Jones, N.R.V.; Forouhi, N.G.; Khaw, K.-T.; Wareham, N.J.; Monsivais, P. Accordance to the Dietary Approaches to Stop Hypertension Diet Pattern and Cardiovascular Disease in a British, Population-Based Cohort. Eur. J. Epidemiol. 2018, 33, 235-244. [CrossRef]

133. Mertens, E.; Markey, O.; Geleijnse, J.M.; Lovegrove, J.A.; Givens, D.I. Adherence to a Healthy Diet in Relation to Cardiovascular Incidence and Risk Markers: Evidence from the Caerphilly Prospective Study. Eur. J. Nutr. 2018, 57, 1245-1258. [CrossRef] [PubMed]

134. Sanches Machado d'Almeida, K.; Ronchi Spillere, S.; Zuchinali, P.; Corrêa Souza, G. Mediterranean Diet and Other Dietary Patterns in Primary Prevention of Heart Failure and Changes in Cardiac Function Markers: A Systematic Review. Nutrients 2018, 10, 58. [CrossRef] [PubMed]

135. Jones-McLean, E.; Hu, J.; Greene-Finestone, L.S.; De Groh, M. A DASH Dietary Pattern and the Risk of Colorectal Cancer in Canadian Adults. Health Promot. Chronic. Dis. Prev. Can. 2015, 35, 12-20. [CrossRef] [PubMed]

136. Mohseni, R.; Mohseni, F.; Alizadeh, S.; Abbasi, S. The Association of Dietary Approaches to Stop Hypertension (DASH) Diet with the Risk of Colorectal Cancer: A Meta-Analysis of Observational Studies. Nutr. Cancer 2020, 72, 778-790. [CrossRef] [PubMed]

137. Le Couteur, D.G.; Solon-Biet, S.; Wahl, D.; Cogger, V.C.; Willcox, B.J.; Willcox, D.C.; Raubenheimer, D.; Simpson, S.J. New Horizons: Dietary Protein, Ageing and the Okinawan Ratio. Age Ageing 2016, 45, 443-447. [CrossRef] [PubMed]

138. Spence, J.D. Nutrition and Risk of Stroke. Nutrients 2019, 11, 647. [CrossRef] [PubMed]

139. Appleby, P.N.; Key, T.J. The Long-Term Health of Vegetarians and Vegans. Proc. Nutr. Soc. 2016, 75, 287-293. [CrossRef]

140. Clarys, P.; Deliens, T.; Huybrechts, I.; Deriemaeker, P.; Vanaelst, B.; De Keyzer, W.; Hebbelinck, M.; Mullie, P. Comparison of Nutritional Quality of the Vegan, Vegetarian, Semi-Vegetarian, Pesco-Vegetarian and Omnivorous Diet. Nutrients 2014, 6, 1318-1332. [CrossRef]

141. Kahleova, H.; Levin, S.; Barnard, N.D. Vegetarian Dietary Patterns and Cardiovascular Disease. Prog. Cardiovasc. Dis. 2018, 61, 54-61. [CrossRef]

142. Huang, T.; Yang, B.; Zheng, J.; Li, G.; Wahlqvist, M.L.; Li, D. Cardiovascular Disease Mortality and Cancer Incidence in Vegetarians: A Meta-Analysis and Systematic Review. Ann. Nutr. Metab. 2012, 60, 233-240. [CrossRef]

143. Kwok, C.S.; Umar, S.; Myint, P.K.; Mamas, M.A.; Loke, Y.K. Vegetarian Diet, Seventh Day Adventists and Risk of Cardiovascular Mortality: A Systematic Review and Meta-Analysis. Int. J. Cardiol. 2014, 176, 680-686. [CrossRef] [PubMed]

144. Dinu, M.; Abbate, R.; Gensini, G.F.; Casini, A.; Sofi, F. Vegetarian, Vegan Diets and Multiple Health Outcomes: A Systematic Review with Meta-Analysis of Observational Studies. Crit. Rev. Food Sci. Nutr. 2017, 57, 3640-3649. [CrossRef] [PubMed]

145. Yokoyama, Y.; Nishimura, K.; Barnard, N.D.; Takegami, M.; Watanabe, M.; Sekikawa, A.; Okamura, T.; Miyamoto, Y. Vegetarian Diets and Blood Pressure: A Meta-Analysis. JAMA Intern. Med. 2014, 174, 577-587. [CrossRef] [PubMed]

146. Sofi, F.; Dinu, M.; Pagliai, G.; Cesari, F.; Gori, A.M.; Sereni, A.; Becatti, M.; Fiorillo, C.; Marcucci, R.; Casini, A. Low-Calorie Vegetarian Versus Mediterranean Diets for Reducing Body Weight and Improving Cardiovascular Risk Profile: CARDIVEG Study (Cardiovascular Prevention With Vegetarian Diet). Circulation 2018, 137, 1103-1113. [CrossRef]

147. Olfert, M.D.; Wattick, R.A. Vegetarian Diets and the Risk of Diabetes. Curr. Diab. Rep. 2018, 18, 101. [CrossRef]

148. Pawlak, R. Vegetarian Diets in the Prevention and Management of Diabetes and Its Complications. Diabetes Spectr. 2017, $30,82-88$. [CrossRef]

149. Chiu, T.H.T.; Pan, W.-H.; Lin, M.-N.; Lin, C.-L. Vegetarian Diet, Change in Dietary Patterns, and Diabetes Risk: A Prospective Study. Nutr. Diabetes 2018, 8, 12. [CrossRef] 
150. Kahleova, H.; Matoulek, M.; Malinska, H.; Oliyarnik, O.; Kazdova, L.; Neskudla, T.; Skoch, A.; Hajek, M.; Hill, M.; Kahle, M.; et al. Vegetarian Diet Improves Insulin Resistance and Oxidative Stress Markers More than Conventional Diet in Subjects with Type 2 Diabetes. Diabet. Med. 2011, 28, 549-559. [CrossRef]

151. Molina-Montes, E.; Salamanca-Fernández, E.; Garcia-Villanova, B.; Sánchez, M.J. The Impact of Plant-Based Dietary Patterns on Cancer-Related Outcomes: A Rapid Review and Meta-Analysis. Nutrients 2020, 12, 2010. [CrossRef]

152. Chang, Y.-J.; Hou, Y.-C.; Chen, L.-J.; Wu, J.-H.; Wu, C.-C.; Chang, Y.-J.; Chung, K.-P. Is Vegetarian Diet Associated with a Lower Risk of Breast Cancer in Taiwanese Women? BMC Public Health 2017, 17, 800. [CrossRef]

153. Tantamango-Bartley, Y.; Jaceldo-Siegl, K.; Fan, J.; Fraser, G. Vegetarian Diets and the Incidence of Cancer in a Low-Risk Population. Cancer Epidemiol. Biomark. Prev. 2013, 22, 286-294. [CrossRef] [PubMed]

154. Tantamango-Bartley, Y.; Knutsen, S.F.; Knutsen, R.; Jacobsen, B.K.; Fan, J.; Beeson, W.L.; Sabate, J.; Hadley, D.; Jaceldo-Siegl, K.; Penniecook, J.; et al. Are Strict Vegetarians Protected against Prostate Cancer? Am. J. Clin. Nutr. 2016, 103, 153-160. [CrossRef] [PubMed]

155. Orlich, M.J.; Singh, P.N.; Sabaté, J.; Fan, J.; Sveen, L.; Bennett, H.; Knutsen, S.F.; Beeson, W.L.; Jaceldo-Siegl, K.; Butler, T.L.; et al. Vegetarian Dietary Patterns and the Risk of Colorectal Cancers. JAMA Intern. Med. 2015, 175, 767-776. [CrossRef]

156. Burns-Whitmore, B.; Froyen, E.; Heskey, C.; Parker, T.; San Pablo, G. Alpha-Linolenic and Linoleic Fatty Acids in the Vegan Diet: Do They Require Dietary Reference Intake/Adequate Intake Special Consideration? Nutrients 2019, 11, 2365. [CrossRef] [PubMed]

157. Fallon, N.; Dillon, S.A. Low Intakes of Iodine and Selenium Amongst Vegan and Vegetarian Women Highlight a Potential Nutritional Vulnerability. Front. Nutr. 2020, 7, 72. [CrossRef]

158. Cohen, S.; Nathan, J.A.; Goldberg, A.L. Muscle Wasting in Disease: Molecular Mechanisms and Promising Therapies. Nat. Rev. Drug Discov. 2015, 14, 58-74. [CrossRef]

159. Benjamin, O.; Lappin, S.L. Kwashiorkor. In StatPearls; StatPearls Publishing: Treasure Island, FL, USA, 2020.

160. Micha, R.; Shulkin, M.L.; Peñalvo, J.L.; Khatibzadeh, S.; Singh, G.M.; Rao, M.; Fahimi, S.; Powles, J.; Mozaffarian, D. Etiologic Effects and Optimal Intakes of Foods and Nutrients for Risk of Cardiovascular Diseases and Diabetes: Systematic Reviews and Meta-Analyses from the Nutrition and Chronic Diseases Expert Group (NutriCoDE). PLoS ONE 2017, 12, e0175149. [CrossRef]

161. Abbayya, K.; Puthanakar, N.Y.; Naduwinmani, S.; Chidambar, Y.S. Association between Periodontitis and Alzheimer's Disease. N. Am. J. Med. Sci. 2015, 7, 241-246. [CrossRef]

162. Michaud, D.S.; Fu, Z.; Shi, J.; Chung, M. Periodontal Disease, Tooth Loss, and Cancer Risk. Epidemiol. Rev. 2017, 39 , 49-58. [CrossRef]

163. Lockhart, P.B.; Bolger, A.F.; Papapanou, P.N.; Osinbowale, O.; Trevisan, M.; Levison, M.E.; Taubert, K.A.; Newburger, J.W.; Gornik, H.L.; Gewitz, M.H.; et al. Periodontal Disease and Atherosclerotic Vascular Disease: Does the Evidence Support an Independent Association? A Scientific Statement from the American Heart Association. Circulation 2012, 125, 2520-2544. [CrossRef]

164. Soto-Barreras, U.; Olvera-Rubio, J.O.; Loyola-Rodriguez, J.P.; Reyes-Macias, J.F.; Martinez-Martinez, R.E.; Patiño-Marin, N.; Martinez-Castañon, G.A.; Aradillas-Garcia, C.; Little, J.W. Peripheral Arterial Disease Associated with Caries and Periodontal Disease. J. Periodontol. 2013, 84, 486-494. [CrossRef] [PubMed]

165. Belinga, L.E.E.; Ngan, W.B.; Lemougoum, D.; Nlo'o, A.S.P.E.; Bongue, B.; Ngono, A.; Mandengue, S.H.; Sembene, M. Association between Periodontal Diseases and Cardiovascular Diseases in Cameroon. J. Public Health Afr. 2018, 9, 761. [CrossRef] [PubMed]

166. Xu, S.; Song, M.; Xiong, Y.; Liu, X.; He, Y.; Qin, Z. The Association between Periodontal Disease and the Risk of Myocardial Infarction: A Pooled Analysis of Observational Studies. BMC Cardiovasc. Disord. 2017, 17, 50. [CrossRef] [PubMed]

167. Rydén, L.; Buhlin, K.; Ekstrand, E.; De Faire, U.; Gustafsson, A.; Holmer, J.; Kjellström, B.; Lindahl, B.; Norhammar, A.; Nygren, Å.; et al. Periodontitis Increases the Risk of a First Myocardial Infarction: A Report From the PAROKRANK Study. Circulation 2016, 133, 576-583. [CrossRef] [PubMed]

168. Renvert, S.; Ohlsson, O.; Pettersson, T.; Persson, G.R. Periodontitis: A Future Risk of Acute Coronary Syndrome? A Follow-up Study over 3 Years. J. Periodontol. 2010, 81, 992-1000. [CrossRef] [PubMed]

169. Chou, S.-H.; Tung, Y.-C.; Lin, Y.-S.; Wu, L.-S.; Lin, C.-P.; Liou, E.J.-W.; Chang, C.-J.; Kung, S.; Chu, P.-H. Major Adverse Cardiovascular Events in Treated Periodontitis: A Population-Based Follow-Up Study from Taiwan. PLoS ONE 2015, 10, e0130807. [CrossRef]

170. Leira, Y.; Seoane, J.; Blanco, M.; Rodríguez-Yáñez, M.; Takkouche, B.; Blanco, J.; Castillo, J. Association between Periodontitis and Ischemic Stroke: A Systematic Review and Meta-Analysis. Eur. J. Epidemiol. 2017, 32, 43-53. [CrossRef]

171. Sfyroeras, G.S.; Roussas, N.; Saleptsis, V.G.; Argyriou, C.; Giannoukas, A.D. Association between Periodontal Disease and Stroke. J. Vasc. Surg. 2012, 55, 1178-1184. [CrossRef]

172. Leng, W.-D.; Zeng, X.-T.; Kwong, J.S.W.; Hua, X.-P. Periodontal Disease and Risk of Coronary Heart Disease: An Updated Meta-Analysis of Prospective Cohort Studies. Int. J. Cardiol. 2015, 201, 469-472. [CrossRef]

173. De Oliveira, F.J.; Vieira, R.W.; Coelho, O.R.; Petrucci, O.; De Oliveira, P.P.M.; Antunes, N.; De Oliveira, I.P.F.; Antunes, E. Systemic Inflammation Caused by Chronic Periodontite in Patients Victims of Acute Ischemic Heart Attack. Rev. Bras. Cir. Cardiovasc. 2010, 25, 51-58. [CrossRef]

174. Arora, N.; Papapanou, P.N.; Rosenbaum, M.; Jacobs, D.R.; Desvarieux, M.; Demmer, R.T. Periodontal Infection, Impaired Fasting Glucose and Impaired Glucose Tolerance: Results from the Continuous National Health and Nutrition Examination Survey 2009-2010. J. Clin. Periodontol. 2014, 41, 643-652. [CrossRef] 
175. Bascones-Martínez, A.; Muñoz-Corcuera, M.; Bascones-Ilundain, J. Diabetes and periodontitis: A bidirectional relationship. Med. Clin. 2015, 145, 31-35. [CrossRef]

176. Llambés, F.; Arias-Herrera, S.; Caffesse, R. Relationship between Diabetes and Periodontal Infection. World J. Diabetes 2015, 6, 927-935. [CrossRef] [PubMed]

177. Engebretson, S.; Kocher, T. Evidence That Periodontal Treatment Improves Diabetes Outcomes: A Systematic Review and Meta-Analysis. J. Clin. Periodontol. 2013, 40 (Suppl. 14), S153-S163. [CrossRef] [PubMed]

178. Teshome, A.; Yitayeh, A. The Effect of Periodontal Therapy on Glycemic Control and Fasting Plasma Glucose Level in Type 2 Diabetic Patients: Systematic Review and Meta-Analysis. BMC Oral Health 2016, 17, 31. [CrossRef] [PubMed]

179. Faggion, C.M.; Cullinan, M.P.; Atieh, M. An Overview of Systematic Reviews on the Effectiveness of Periodontal Treatment to Improve Glycaemic Control. J. Periodontal. Res. 2016, 51, 716-725. [CrossRef] [PubMed]

180. Liccardo, D.; Cannavo, A.; Spagnuolo, G.; Ferrara, N.; Cittadini, A.; Rengo, C.; Rengo, G. Periodontal Disease: A Risk Factor for Diabetes and Cardiovascular Disease. Int. J. Mol. Sci. 2019, 20, 1414. [CrossRef] [PubMed]

181. Liu, L.S.; Gkranias, N.; Farias, B.; Spratt, D.; Donos, N. Differences in the Subgingival Microbial Population of Chronic Periodontitis in Subjects with and without Type 2 Diabetes Mellitus-a Systematic Review. Clin. Oral Investig. 2018, 22, $2743-2762$. [CrossRef] [PubMed]

182. Aoyama, N.; Suzuki, J.-I.; Kobayashi, N.; Hanatani, T.; Ashigaki, N.; Yoshida, A.; Shiheido, Y.; Sato, H.; Izumi, Y.; Isobe, M. Increased Oral Porphyromonas Gingivalis Prevalence in Cardiovascular Patients with Uncontrolled Diabetes Mellitus. Int. Heart J. 2018, 59, 802-807. [CrossRef]

183. Corbella, S.; Veronesi, P.; Galimberti, V.; Weinstein, R.; Del Fabbro, M.; Francetti, L. Is Periodontitis a Risk Indicator for Cancer? A Meta-Analysis. PLoS ONE 2018, 13, e0195683. [CrossRef]

184. Güven, D.C.; Dizdar, Ö.; Akman, A.C.; Berker, E.; Yekedüz, E.; Ceylan, F.; Başpınar, B.; Akbıyık, İ.; Aktaş, B.Y.; Yüce, D.; et al. Evaluation of Cancer Risk in Patients with Periodontal Diseases. Turk. J. Med. Sci. 2019, 49, 826-831. [CrossRef] [PubMed]

185. Maisonneuve, P.; Amar, S.; Lowenfels, A.B. Periodontal Disease, Edentulism, and Pancreatic Cancer: A Meta-Analysis. Ann. Oncol. 2017, 28, 985-995. [CrossRef] [PubMed]

186. Zeng, X.-T.; Xia, L.-Y.; Zhang, Y.-G.; Li, S.; Leng, W.-D.; Kwong, J.S.W. Periodontal Disease and Incident Lung Cancer Risk: A Meta-Analysis of Cohort Studies. J. Periodontol. 2016, 87, 1158-1164. [CrossRef] [PubMed]

187. Shao, J.; Wu, L.; Leng, W.-D.; Fang, C.; Zhu, Y.-J.; Jin, Y.-H.; Zeng, X.-T. Periodontal Disease and Breast Cancer: A Meta-Analysis of 1,73,162 Participants. Front. Oncol. 2018, 8, 601. [CrossRef] [PubMed]

188. Ye, L.; Jiang, Y.; Liu, W.; Tao, H. Correlation between Periodontal Disease and Oral Cancer Risk: A Meta-Analysis. J. Cancer Res. Ther. 2016, 12, C237-C240. [CrossRef]

189. Zeng, X.-T.; Deng, A.-P.; Li, C.; Xia, L.-Y.; Niu, Y.-M.; Leng, W.-D. Periodontal Disease and Risk of Head and Neck Cancer: A Meta-Analysis of Observational Studies. PLoS ONE 2013, 8, e79017. [CrossRef]

190. Inaba, H.; Sugita, H.; Kuboniwa, M.; Iwai, S.; Hamada, M.; Noda, T.; Morisaki, I.; Lamont, R.J.; Amano, A. Porphyromonas Gingivalis Promotes Invasion of Oral Squamous Cell Carcinoma through Induction of ProMMP9 and Its Activation. Cell. Microbiol. 2014, 16, 131-145. [CrossRef]

191. Gao, S.; Li, S.; Ma, Z.; Liang, S.; Shan, T.; Zhang, M.; Zhu, X.; Zhang, P.; Liu, G.; Zhou, F.; et al. Presence of Porphyromonas Gingivalis in Esophagus and Its Association with the Clinicopathological Characteristics and Survival in Patients with Esophageal Cancer. Infect. Agents Cancer 2016, 11, 3. [CrossRef]

192. Kostic, A.D.; Chun, E.; Robertson, L.; Glickman, J.N.; Gallini, C.A.; Michaud, M.; Clancy, T.E.; Chung, D.C.; Lochhead, P.; Hold, G.L.; et al. Fusobacterium Nucleatum Potentiates Intestinal Tumorigenesis and Modulates the Tumor-Immune Microenvironment. Cell Host Microbe 2013, 14, 207-215. [CrossRef]

193. Ojo, O. Nutrition and Chronic Conditions. Nutrients 2019, 11, 459. [CrossRef]

194. Yu, G.; Dye, B.A.; Gail, M.H.; Shi, J.; Klepac-Ceraj, V.; Paster, B.J.; Wang, G.-Q.; Wei, W.-Q.; Fan, J.-H.; Qiao, Y.-L.; et al. The Association between the Upper Digestive Tract Microbiota by HOMIM and Oral Health in a Population-Based Study in Linxian, China. BMC Public Health 2014, 14, 1110. [CrossRef] [PubMed]

195. Rosier, B.T.; De Jager, M.; Zaura, E.; Krom, B.P. Historical and Contemporary Hypotheses on the Development of Oral Diseases: Are We There Yet? Front. Cell. Infect. Microbiol. 2014, 4, 92. [CrossRef] [PubMed]

196. Li, X.; Kolltveit, K.M.; Tronstad, L.; Olsen, I. Systemic Diseases Caused by Oral Infection. Clin. Microbiol. Rev. 2000, 13, 547-558. [CrossRef] [PubMed]

197. Bui, F.Q.; Almeida-da-Silva, C.L.C.; Huynh, B.; Trinh, A.; Liu, J.; Woodward, J.; Asadi, H.; Ojcius, D.M. Association between Periodontal Pathogens and Systemic Disease. Biomed. J. 2019, 42, 27-35. [CrossRef]

198. Nabee, Z.; Jeewon, R.; Pugo-Gunsam, P. Oral Dysbacteriosis in Type 2 Diabetes and Its Role in the Progression to Cardiovascular Disease. Afr. Health Sci. 2017, 17, 1082-1091. [CrossRef]

199. Ford, P.J.; Raphael, S.L.; Cullinan, M.P.; Jenkins, A.J.; West, M.J.; Seymour, G.J. Why Should a Doctor Be Interested in Oral Disease? Expert Rev. Cardiovasc. Ther. 2010, 8, 1483-1493. [CrossRef]

200. Atarashi, K.; Suda, W.; Luo, C.; Kawaguchi, T.; Motoo, I.; Narushima, S.; Kiguchi, Y.; Yasuma, K.; Watanabe, E.; Tanoue, T.; et al. Ectopic Colonization of Oral Bacteria in the Intestine Drives TH1 Cell Induction and Inflammation. Science 2017, 358, 359-365. [CrossRef] 
201. Flynn, K.J.; Baxter, N.T.; Schloss, P.D. Metabolic and Community Synergy of Oral Bacteria in Colorectal Cancer. $m$ Sphere $2016,1$. [CrossRef]

202. Du Teil Espina, M.; Gabarrini, G.; Harmsen, H.J.M.; Westra, J.; Van Winkelhoff, A.J.; Van Dijl, J.M. Talk to Your Gut: The Oral-Gut Microbiome Axis and Its Immunomodulatory Role in the Etiology of Rheumatoid Arthritis. FEMS Microbiol. Rev. 2019, 43, 1-18. [CrossRef]

203. Maekawa, T.; Krauss, J.L.; Abe, T.; Jotwani, R.; Triantafilou, M.; Triantafilou, K.; Hashim, A.; Hoch, S.; Curtis, M.A.; Nussbaum, G.; et al. Porphyromonas Gingivalis Manipulates Complement and TLR Signaling to Uncouple Bacterial Clearance from Inflammation and Promote Dysbiosis. Cell Host Microbe 2014, 15, 768-778. [CrossRef]

204. Cena, H.; Calder, P.C. Defining a Healthy Diet: Evidence for The Role of Contemporary Dietary Patterns in Health and Disease. Nutrients 2020, 12, 334. [CrossRef] [PubMed]

205. Laiola, M.; De Filippis, F.; Vitaglione, P.; Ercolini, D. A Mediterranean Diet Intervention Reduces the Levels of Salivary Periodontopathogenic Bacteria in Overweight and Obese Subjects. Appl. Environ. Microbiol. 2020, 86. [CrossRef] [PubMed]

206. Holmer, H.; Widén, C.; Wallin Bengtsson, V.; Coleman, M.; Wohlfart, B.; Steen, S.; Persson, R.; Sjöberg, K. Improved General and Oral Health in Diabetic Patients by an Okinawan-Based Nordic Diet: A Pilot Study. Int. J. Mol. Sci. 2018, 19, 1949. [CrossRef] [PubMed]

207. Sheiham, A.; Steele, J.G.; Marcenes, W.; Lowe, C.; Finch, S.; Bates, C.J.; Prentice, A.; Walls, A.W. The Relationship among Dental Status, Nutrient Intake, and Nutritional Status in Older People. J. Dent. Res. 2001, 80, 408-413. [CrossRef] [PubMed]

208. Mendonça, D.D.; Furtado, M.V.; Sarmento, R.A.; Nicoletto, B.B.; Souza, G.C.; Wagner, T.P.; Christofoli, B.R.; Polanczyk, C.A.; Haas, A.N. Periodontitis and Tooth Loss Have Negative Impact on Dietary Intake: A Cross-Sectional Study with Stable Coronary Artery Disease Patients. J. Periodontol. 2019, 90, 1096-1105. [CrossRef] [PubMed]

209. Jansson, H.; Wahlin, Å.; Johansson, V.; Åkerman, S.; Lundegren, N.; Isberg, P.-E.; Norderyd, O. Impact of Periodontal Disease Experience on Oral Health-Related Quality of Life. J. Periodontol. 2014, 85, 438-445. [CrossRef]

210. Tonetti, M.S.; Jepsen, S.; Jin, L.; Otomo-Corgel, J. Impact of the Global Burden of Periodontal Diseases on Health, Nutrition and Wellbeing of Mankind: A Call for Global Action. J. Clin. Periodontol. 2017, 44, 456-462. [CrossRef]

211. Chong, S.; Ding, D.; Byun, R.; Comino, E.; Bauman, A.; Jalaludin, B. Lifestyle Changes After a Diagnosis of Type 2 Diabetes. Diabetes Spectr. 2017, 30, 43-50. [CrossRef]

212. Coa, K.I.; Epstein, J.B.; Ettinger, D.; Jatoi, A.; McManus, K.; Platek, M.E.; Price, W.; Stewart, M.; Teknos, T.N.; Moskowitz, B. The Impact of Cancer Treatment on the Diets and Food Preferences of Patients Receiving Outpatient Treatment. Nutr. Cancer 2015, 67, 339-353. [CrossRef]

213. Carrouel, F.; Viennot, S.; Santamaria, J.; Veber, P.; Bourgeois, D. Quantitative Molecular Detection of 19 Major Pathogens in the Interdental Biofilm of Periodontally Healthy Young Adults. Front. Microbiol. 2016, 7, 840. [CrossRef]

214. Carrouel, F.; Llodra, J.C.; Viennot, S.; Santamaria, J.; Bravo, M.; Bourgeois, D. Access to Interdental Brushing in Periodontal Healthy Young Adults: A Cross-Sectional Study. PLoS ONE 2016, 11, e0155467. [CrossRef] [PubMed]

215. Prevention of Cardiovascular Disease: Guidelines for Assessment and Management of Cardiovascular Risk; World Health Organization (Ed.) World Health Organization: Geneva, Switzerland, 2007; ISBN 978-92-4-154717-8.

216. Global Report on Diabetes; Roglic, G.; World Health Organization (Eds.) World Health Organization: Geneva, Switzerland, 2016; ISBN 978-92-4-156525-7.

217. White, M.C.; Holman, D.M.; Boehm, J.E.; Peipins, L.A.; Grossman, M.; Henley, S.J. Age and Cancer Risk: A Potentially Modifiable Relationship. Am. J. Prev. Med. 2014, 46, S7-S15. [CrossRef] [PubMed]

218. Essential Nutrition Actions: Mainstreaming Nutrition through the Life-Course. Available online: https://www.who.int/ publications-detail-redirect/9789241515856 (accessed on 22 December 2020).

219. Global Action Plan for the Prevention and Control of NCDs 2013-2020. Available online: https:/ /www.who.int/publicationsdetail-redirect/9789241506236 (accessed on 22 December 2020).

220. Petersen, P.E. World Health Organization Global Policy for Improvement of Oral Health-World Health Assembly 2007. Int. Dent. J. 2008, 58, 115-121. [CrossRef] [PubMed]

221. Khanbodaghi, A.; Natto, Z.S.; Forero, M.; Loo, C.Y. Effectiveness of Interprofessional Oral Health Program for Pediatric Nurse Practitioner Students at Northeastern University, United States. BMC Oral Health 2019, 19, 170. [CrossRef] [PubMed]

222. Tonetti, M.S.; Eickholz, P.; Loos, B.G.; Papapanou, P.; Van der Velden, U.; Armitage, G.; Bouchard, P.; Deinzer, R.; Dietrich, T.; Hughes, F.; et al. Principles in Prevention of Periodontal Diseases: Consensus Report of Group 1 of the 11th European Workshop on Periodontology on Effective Prevention of Periodontal and Peri-Implant Diseases. J. Clin. Periodontol. 2015, 42 (Suppl. 16), S5-S11. [CrossRef]

223. Bourgeois, D.; Bravo, M.; Llodra, J.-C.; Inquimbert, C.; Viennot, S.; Dussart, C.; Carrouel, F. Calibrated Interdental Brushing for the Prevention of Periodontal Pathogens Infection in Young Adults-A Randomized Controlled Clinical Trial. Sci. Rep. 2019, 9, 15127. [CrossRef]

224. Dion, N.; Cotart, J.-L.; Rabilloud, M. Correction of Nutrition Test Errors for More Accurate Quantification of the Link between Dental Health and Malnutrition. Nutrition 2007, 23, 301-307. [CrossRef] 